\title{
Comparative anatomy of the middle ear in some lizard species with comments on the evolutionary changes within Squamata
}

\author{
Paola M. Sánchez-Martínez ${ }^{\text {Corresp., } 1}{ }^{\text {, Juan D. Daza }}{ }^{2}$, Julio M. Hoyos Hoyos ${ }^{\text {Corresp. 1, } 3}$ \\ 1 Laboratorio de Sistemática Morfológica y Biogeografía de Vertebrados, Departamento de Biología Facultad de Ciencias, Pontificia Universidad Javeriana, \\ Bogotá, Cundinamarca, Colombia \\ 2 Department of Biological Sciences, Sam Houston State University, Huntsville, Texas, United States \\ 3 Unidad de Ecología y Sistemática (UNESIS), Departamento de Biología, Facultad de Ciencias, Pontificia Universidad Javeriana, Bogotá, Cundinamarca, \\ Colombia
}

Corresponding Authors: Paola M. Sánchez-Martínez, Julio M. Hoyos Hoyos

Email address: paola.sanmart@gmail.com,jmhoyos@javeriana.edu.co

The middle ear of lizards is composed of three anatomical elements: columella, extracolumella, and tympanic membrane, with some exceptions that show modifications of this anatomy. The main function of the middle ear is transforming sound waves into vibrations and transmitting these to the inner ear. Most middle ear studies mainly focus on its functional aspects, while few describe the anatomy in detail. In lizards, the morphology of the columella is highly conservative, while the extracolumella shows variation in its presence/absence, size, and the number of processes present on the structure. In this work, we used diaphanized and double-stained specimens of 38 species of lizards belonging to 24 genera to study the middle ear's morphology in a comparative framework. Results presented here indicate more variation in the morphology of the extracolumella than previously known. This variation in the extracolumella is found mainly in the pars superior and anterior processes, while the pars inferior and the posterior process are more constant in morphology. We also provide new information about the shape of gekkotan extracolumella, including traits that are diagnostic for the iguanid and gekkonid middle ear types. The data collected in this study were combined with information from published descriptive works. The new data included here refers to the length of the columella relative to the extracolumella central axis length, the general structure of the extracolumella, and the presence of the internal process. These characters were included in ancestral reconstruction analysis using Bayesian and parsimony approaches. The results indicate high levels of homoplasy in the variation of the columella-extracolumella ratio, providing a better understanding of the ratio variation among lizards. Additionally, the presence of four processes in the extracolumella is the ancestral state for Gekkota, Pleurodonta, and Xantusiidae, and the absence of the internal processes is the ancestral state for Gekkota, Gymnophthalmidae, and Scincidae; despite the fact that these groups convergently 
develop these character states, they could be used in combination with other characters to diagnose these clades. The posterior extension in the pars superior and an anterior process with some small and sharp projections is also a diagnostic trait for Gekkota. A more accurate description of each process of the extracolumella and its variation needs to be evaluated in a comprehensive analysis, including a greater number of species. Although the number of taxa sampled in this study is small considering the vast diversity of lizards, the results provide an overall idea of the amount of variation of the middle ear while helping to infer the evolutionary history of the lizard middle ear. 
1 Comparative anatomy of the middle ear in some

2 lizard species with comments on the evolutionary

3 changes within Squamata.

4

5 Paola M. Sánchez-Martínez ${ }^{1}$, Juan D. Daza ${ }^{2}$, Julio M. Hoyos Hoyos ${ }^{1,3}$

6

$7 \quad{ }^{1}$ Laboratorio de Sistemática Morfológica y Biogeografía de Vertebrados, Departamento de

8 Biología Facultad de Ciencias, Pontificia Universidad Javeriana, Bogotá, Colombia.

9

${ }^{2}$ Department of Biological Sciences, Sam Houston State University, Huntsville, Texas, USA.

${ }^{3}$ Unidad de Ecología y Sistemática (UNESIS), Departamento de Biología, Facultad de Ciencias,

Pontificia Universidad Javeriana, Bogotá, Colombia.

14

Email address: paola.sanmart@gmail.com

21

Julio M. Hoyos Hoyos ${ }^{1,3}$

23

Email address: jmhoyos@javeriana.edu.co

25

26

27 


\section{Abstract}

38 The middle ear of lizards is composed of three anatomical elements: columella, extracolumella,

39 and tympanic membrane, with some exceptions that show modifications of this anatomy. The

40 main function of the middle ear is transforming sound waves into vibrations and transmitting

41 these to the inner ear. Most middle ear studies mainly focus on its functional aspects, while few

42 describe the anatomy in detail. In lizards, the morphology of the columella is highly

43 conservative, while the extracolumella shows variation in its presence/absence, size, and the

44 number of processes present on the structure. In this work, we used diaphanized and double-

45 stained specimens of 38 species of lizards belonging to 24 genera to study the middle ear's

46 morphology in a comparative framework. Results presented here indicate more variation in the

47 morphology of the extracolumella than previously known. This variation in the extracolumella is

48 found mainly in the pars superior and anterior processes, while the pars inferior and the posterior

49 process are more constant in morphology. We also provide new information about the shape of

50 gekkotan extracolumella, including traits that are diagnostic for the iguanid and gekkonid middle

51 ear types. The data collected in this study were combined with information from published

52 descriptive works. The new data included here refers to the length of the columella relative to the

53 extracolumella central axis length, the general structure of the extracolumella, and the presence

54 of the internal process. These characters were included in ancestral reconstruction analysis using

55 Bayesian and parsimony approaches. The results indicate high levels of homoplasy in the

56 variation of the columella-extracolumella ratio, providing a better understanding of the ratio

57 variation among lizards. Additionally, the presence of four processes in the extracolumella is the

58 ancestral state for Gekkota, Pleurodonta, and Xantusiidae, and the absence of the internal

59 processes is the ancestral state for Gekkota, Gymnophthalmidae, and Scincidae; despite the fact

60 that these groups convergently develop these character states, they could be used in combination 
61 with other characters to diagnose these clades. The posterior extension in the pars superior and

62 an anterior process with some small and sharp projections is also a diagnostic trait for Gekkota.

63 A more accurate description of each process of the extracolumella and its variation needs to be

64 evaluated in a comprehensive analysis, including a greater number of species. Although the

65 number of taxa sampled in this study is small considering the vast diversity of lizards, the results

66 provide an overall idea of the amount of variation of the middle ear while helping to infer the

67 evolutionary history of the lizard middle ear.

68

\section{Introduction}

70 The ear is a complex system that performs a dual function - equilibrium and hearing. In reptiles,

71 the ear has been described in three divisions: the outer, middle, and inner ear (Baird, 1970). The

72 outer ear includes the meatal cavity, closure muscles, and modifications of skin that detect sound

73 waves and conduct them to the middle ear. In the middle ear of lizards (in most species of lizards

74 composed of the tympanic membrane, extracolumella, and columella) the sound waves are

75 transformed into vibrations, which are transmitted to the inner ear. The inner ear also is formed

76 by the membranous or endolymphatic labyrinth where the sense organs are located, and the

77 perilymphatic labyrinth is an area of fluid-filled cavities in which the movements continue as

78 fluid oscillations, impacting the cochlea (Baird, 1960, 1970; Wever, 1978). Most of the studies

79 around the lizard ear are focused on the study of processes of conductivity of sound, and the

80 electrophysiological aspects of the inner ear (e.g., Shute \& Bellairs, 1953; Baird, 1960; Wever et

81 al., 1963; Schmidt, 1964; Wever et al., 1965; Baird, 1967; Suga \& Campbell, 1967; Wever,

82 1967, 1970; Baird \& Marovitz, 1971; Wever, 1971; Manley, 1972a; Wever \& Gans, 1972;

83 Miller, 1974; Werner, 1976; Manley, 2000; Werner \& Igić, 2002; Wibowo, Brockhausen \& 
84 Köppl, 2009; Manley, 2011). The standard approach of studies on the middle ear has been

85 mainly focused on investigating the functional aspects of the transformation of sound waves into

86 vibrations, with some work describing a few morphological features (e.g., Wever \& Peterson,

87 1963; Wever \& Wener, 1970; Manley, 1972b; Werner \& Wever, 1972; Wever, 1973; Manley,

88 2011; Han \& Young, 2016). Other studies, although less common, have concentrated specifically

89 on the anatomy of the middle and outer ear (e.g., Versluys, 1898; Earle, 1961a; Earle, 1961b;

90 Earle, 1961c; Posner \& Chiasson, 1966; Iordansky, 1968; Wever, 1978). The studies that could

91 be considered the most relevant contributions to knowledge of the middle ear in lizards are those

92 by Versluys (1898) and Wever (1978). Versluys (1898) shared essential information about the

93 morphology of the structures and associated muscles. Wever (1978) contributed to the

94 knowledge of the function of the inner ear, describing details of the structures of the middle and

95 outer ear and its taxonomic distribution, information that has been used in cladistics studies (e.g.,

96 Kluge, 1987).

97 In lizards, the most common pattern of the middle ear (Fig. 1) is a simple structure composed

98 of the columella and extracolumella that are suspended in the tympanic cavity, and the tympanic

99 membrane. Some groups also show the internal process, which is an additional middle ear

100 cartilaginous element associated with the extracolumella (Versluys, 1898; Baird, 1970; Wever,

101 1978; Saunders et al., 2000). The columella (Fig. 1A) is a slender rod whose main part is

102 osseous, and its distal end is cartilaginous. The proximal end is formed by a footplate; this end of

103 the bone inserts itself into the oval window which is the opening of the otic capsule leading to

104 the inner ear and connects with the cochlea. At the distal end of the columella, the bone is

105 connected to the extracolumella. The extracolumella (Fig. 1A-B) is a cartilaginous structure

106 forming a main shaft that shows a variable number of processes (two to four), namely: pars 
107 superior and pars inferior, the anterior and posterior processes. These processes meet the internal 108 surface of the tympanic membrane in a cruciform arrangement. The principal extracolumellar 109 processes are the pars superior and pars inferior, which form a vertical shaft whose function is to 110 transmit the vibrations and stretch and tense the tympanic membrane. In most of the species, the 111 pars superior and inferior are associated with the extracolumellar and intratympanic ligaments,

112 respectively. Also, in most of the gekkotans, the pars superior is associated with the 113 extracolumellar muscle that probably exercises tension on the membrane and the other structures 114 of the middle ear (Wever \& Werner, 1970; Wever, 1978). The anterior and posterior processes 115 arise from the pars superior and pars inferior and are smaller than the structures from which they 116 originate, sometimes being poorly defined or absent in some species (Wever, 1978). When these

117 extracolumellar processes are developed, they attach the extracolumella to the tympanic 118 membrane to reduce movements of the extracolumella and help to tense the membrane surface 119 (Baird, 1970; Wever, 1978; Saunders et al., 2000). The internal process is a complementary 120 extracolumellar structure that is present only in iguanians and related species. This process 121 originates from the extracolumella and serve to link the extracolumella to the quadrate bone. In 122 species where the internal process is absent, the support of the columellar system is given by a 123 fold of mucous membrane (Wever, 1978). The extracolumella is the element of the middle ear in 124 lizards that displays the most morphological variation. This variation tends to occur in the shape 125 and number of the extracolumellar processes, the presence or absence of the internal process, and 126 the type of the connection between the columella and the extracolumella (Wever, 1978).

127 Based on the overall morphology, Wever \& Werner (1970) defined three main patterns of 128 middle ears in lizards, namely the gekkonid, iguanid, and scincid types. Additionally, different 129 forms that do not correspond to the previous patterns were considered as "divergent" types, 
130 which mostly were morphologies that departed the iguanid type (Wever, 1978). These three

131 standard types exhibit the same primary structure described above but differ in some details

132 associated with both presence and form of certain structures. In the iguanid type (Wever, 1978,

133 Fig. 6-10), the most generalized type in lizards, there is an additional cartilaginous shaft termed

134 the "internal process" by Versluys (1898), which arises from the extracolumellar shaft and

135 expands dorsally and anteriorly to attach to the quadrate bone. In the gekkonid type (Wever,

136 1978, Fig. 6-30), there is no internal process, but there is a tympanic muscle called the

137 "extracolumellar muscle" (Wever \& Werner, 1970), that runs from the distal edge of the pars

138 superior to the ceratohyal process. The scincid type (Wever, 1978, Fig. 6-42) lacks both the

139 internal process and the tympanic muscle; and the divergent types show features that do not

140 match with any of the aforementioned types (Wever, 1978).

141 The middle ear has evolved independently several times in vertebrates (Lombard \& Bolt,

142 1979; Clack, 1997; Clack, 2002; Manley, 2010). In the stem reptiles, the tympanum is absent, and

143 the stapes is bulky. The evolutive changes in the stapes resulted in unique middle-ear morphologies

144 present in each order of living reptiles (Saunders et al., 2000). In lizards, the studies presented by

145 Versluys (1898), Olson (1966), and Baird (1970) made anatomical comparisons of the outer and

146 middle ear among taxa making some evolutionary assumptions. According to Olson (1966), the

147 middle ear is associated with the masticatory apparatus and is therefore highly susceptible to

148 adaptive modifications and, although some morphological types are conservative, others are

149 rather diverse. Thus, the middle ear structures could prove to be useful in providing phylogenetic

150 information within major morphological types, but not when relationships between these types

151 are considered (Olson, 1966). Baird (1970) suggests that in most terrestrial and arboreal lizards,

152 the middle ear corresponds to the iguanid pattern, but it is common to find related taxa that show

153 morphological variations correlated to other features of the ear, or variations that may relate

Peer) reviewing PDF | (2020:12:56089:3:0:NEW 5 Jun 2021) 
154 more directly to habits or habitats. However, this kind of affirmation is preliminary because the

155 diversity of morphologies of the external and middle ear across lizards is barely understood and 156 requires further investigation (Wever, 1968; Baird, 1970). The main objective of this study is to 157 describe the morphological variation of the middle ear in "lizards", using samples from four of 158 the main taxonomic groups [Gekkota, Iguania, Lacertoidea, and Scincoidea (Zheng and Wiens, 159 2016)], and character trait mapping methods to propose a preliminary scenario of middle ear 160 evolution.

161 Since the word "lizard" refers to a paraphyletic group relative to snakes, we must clarify that by 162 using this term we refer to squamates that are not snakes (i.e., Iguania, Gekkota, Scincoidea, 163 Lacertoidea [including Amphisbaena, and Anguimorpha [excluding snakes]). Despite the 164 paraphyletic status of "lizards", it makes sense for us to study them as a whole considering their 165 shared similarities in middle ear structures and their differences with snakes.

\section{Materials \& Methods}

\section{Comparative Anatomy}

169 We examined the middle ear of cleared and double-stained specimens of 38 species of lizards, 170 belonging to 24 genera and 12 families (Table 1). We recognize that this number of species 171 examined is a small percentage of the totality of species of lizards described, however this small 172 sample size is adequate to produce an initial assessment of the morphological differences in the

173 middle ear of lizards. The specimens examined belong to the Colección Herpetológica del Museo

174 Javeriano de Historia Natural Lorenzo Uribe, S.J. - MUJ at Pontificia Universidad Javeriana 175 (Bogotá, Colombia), Colección Herpetológica del Instituto de Ciencias Naturales - ICN at 176 Universidad Nacional de Colombia (Bogotá, Colombia), Museo de Herpetología de la 
177 Universidad de Antioquia - MHUA (Medellín, Colombia), and the Museu de Zoologia da

178 Universidade de São Paulo - MZUSP (São Paulo, Brazil). Voucher specimen information is

179 provided in Table S1. The middle ears of the species studied were described following the

180 nomenclature proposed by Wever (1978) and analyzed in a comparative framework with the data

181 available in the literature. The summary of the variation described is presented in Tables 2 and 3.

182 As a note on taxonomy within this paper, we have considered the genus Mabuya in the broad

183 sense. The genus Mabuya was extensively rearranged in 2012, and here we examined species

184 from the clade referred to as "American Mabuyas," which now encompasses eight genera

185 (Hedges \& Conn, 2012). In this study, we used specimens from two of these American genera

186 (Copeoglossum nigropunctatum and Marisora falconensis) together with other undescribed

187 species, but for simplicity, we have referred all of them to the genus Mabuya s.p.

188

189 Ancestral Reconstruction

190 Character states were coded from direct observations of the material described and from

191 published data. The sources of the information published for each species included in the

192 analysis are given in Table 4. In order to reconstruct the evolutionary changes, the morphological

193 characters defined were optimized on the phylogenetic hypothesis based on molecular data

194 proposed by Zheng \& Wiens (2016), using maximum parsimony (MP) and Bayesian approaches.

195 The parsimony analysis used equal weighting, the characters were considered as unordered and

196 the analysis was performed using MESQUITE 3.5 (Maddison \& Maddison, 2018). The Bayesian

197 analysis used the "ARD" (backward \& forward rates between states) and "ER" (single-rate)

198 models, and was conducted using R 4.0.2 (R Core Team, 2020) and the phytools package

199 (Revell, 2012). To perform the parsimony analysis, we pruned the tree to include only the 
200 species studied here, and in some cases, we edited terminal names following two rules: 1) if

201 several species from a single genus had the same character state, these were collapsed into a

202 single terminal with the genus name (the list of species collapsed and their corresponding

203 terminal taxon are provided in Table S2); 2) if one or more examined taxa were not included in

204 the molecular phylogenetic analysis, these taxa were included as terminals in a polytomy,

205 assuming that the genera are monophyletic. Features with unknown character states were treated 206 as missing "?", and inapplicable characters as dash “-”. To conduct the Bayesian analysis, we 207 pruned the topology by collapsing the genera without data to a single terminal for family.

208 The files used in the analyses are available at Morphobank (O'Leary \& Kaufman, 2012) 209 Project $3551 \mathrm{http}: / /$ morphobank.org/permalink/?P3551

\section{Results}

212 Lizards occupy a wide diversity of habitats (e.g., terrestrial, arboreal, saxicolous, fossorial, 213 sand dwellers, semi-aquatic, and aquatic), and for this reason, it is expected that they exhibit 214 significant variation in their middle ear structure depending on the way and medium through 215 which they perceive sounds. As anticipated, according to the literature, the columella bone is a 216 constant element with an uniaxial organization, although differs in shape and proportions 217 (ranging from being long and thin as in Tupinambis nigropunctatus $=$ Tupinambis teguixin 218 [Jollie, 1960] to short and stumpy as in Calyptommatus leiolepis [Holovacs et al., 2018]). The 219 extracolumella on the other hand, shows more significant variation in the number and shape of 220 its processes (Fig. 1).

221 Columella. The main body of the columella is an elongated osseous rod (Fig. 1A). Its proximal 222 end is formed by an expanded footplate, which inserts into the oval window (the opening that 
223 leads to the inner ear); while at its distal end, the columella connects to the extracolumella. The

224 variation found among the specimens examined was mainly in the presence of the stapedial

225 foramen, the presence of a cartilaginous stalk on the distal end, differences in the length of the

226 columella in relation to the extracolumellar vertical axis, and a slight expansion of the distal end.

227 The variation of the columella observed in the examined specimens is summarized in Table 2.

228 The stapedial foramen (Fig. 2A) pierces the columella near the proximal end, and this opening 229 allows the passage of the stapedial artery (Greer, 1976). In the present study, this character was 230 observed in the gekkotans Gonatodes albogularis, G. concinnatus, Hemidactylus brasilianus, 231 Phelsuma madagascariensis, and Tarentola mauritanica (Fig. 2A). This foramen is absent (Fig.

232 2B) in the remaining species studied, although it has been reported in lizards of the family 233 Dibamidae (Greer, 1976; Estes, de Queiroz \& Gauthier, 1988; Gauthier, Estes \& de Queiroz, 234 1988) and embryonic stages of amphisbaenians (Kearney, 2003).

235 There are some differences in the relationship between the length of the columella and 236 extracolumella. The length of the columella (measured from the footplate to the joint with the 237 extracolumella; Fig. 1A), can be longer (Fig. 2C), subequal (Fig. 3A), or shorter (Fig. 3B), than 238 the length of the extracolumellar vertical axis (taken from the upper edge of the pars superior to 239 the lower edge of the pars inferior; Fig. 1B). In the specimens studied, the length of the 240 columella was longer in Acanthocercus atricollis (Agamidae); Mabuya nigropunctata 241 (Scincidae); Tarentola mauritanica (Phyllodactylidae); and Tretioscincus bifasciatus 242 (Gymnophthalmidae; Fig. 2C). The columella length is similar to the extracolumella vertical axis 243 in Acanthodactylus cf. schmidti (Lacertidae); Anolis spp., (Dactyloidae); Hemidactylus 244 brasilianus and Phelsuma madagascariensis (Gekkonidae); Mabuya spp. (except in M. 245 nigropunctata; Scincidae); Riama striata (Gymnophthalmidae); Stenocercus trachycephalus 
246 (Tropiduridae; Fig. 3A); and Thecadactylus rapicauda (Phyllodactylidae). The columella was

247 shorter in Anadia bogotensis, Gelanesaurus cochranae, Loxopholis rugiceps, Neusticurus

248 medemi, Pholidobolus montium, and P. vertebralis (Gymnophthalmidae); Gonatodes

249 albogularis, G. concinnatus (Sphaerodactylidae; Fig. 2A); Hoplocercus spinosus, Morunasaurus 250 groi (Hoplocercidae); Lialis jicari (Pygopodidae; Fig. 3B); and Tropidurus pinima

251 (Tropiduridae).

252 A slight expansion of the osseous distal end of the columella was observed in Acanthocercus 253 atricollis (Agamidae); Acanthodactylus cf. schmidti (Lacertidae); Anolis spp. (Dactyloidae; Fig. 254 3C); Mabuya spp. (Scincidae); Morunasaurus groi (Hoplocercidae); Lialis jicari (Pygopodidae; 255 Fig. 3B); Loxopholis rugiceps, Pholidobolus vertebralis, Tretioscincus bifasciatus 256 (Gymnophthalmidae; Fig. 2C); Phelsuma madagascariensis (Gekkonidae); Stenocercus 257 trachycephalus (Fig. 3A); and Tropidurus pinima (Tropiduridae). The remaining species do not 258 show this expansion. Two conditions of the distal end of the columella - expanded end or 259 constant size along the columellar shaft - were observed in different specimens of Anadia 260 bogotensis (Gymnophthalmidae), specimen ICN 2987 (slight expansion) and ICN 2178 (constant 261 width).

262 We detected a slight difference in the cartilaginous rim of the footplate. The rim can form a 263 complete ring around the footplate of the columella, as observed in Gonatodes albogularis MUJ264 665, or be a discontinuous and very thin ring, as observed in Anolis auratus MUJ 590. In some 265 specimens, this ring is absent altogether (e.g., Pholidobolus vertebralis ICN 5719). We do not 266 discount that differences in the development of the cartilaginous ring of the footplate could be an 267 artifact of the staining used in the preparations, and may not represent true morphological 268 variation. 
270 Columella-extracolumella joint. This joint varies in the presence/absence of connective tissue

271 and the form of the joint. Connective tissue was observed in Acanthocercus atricollis

272 (Agamidae); Acanthodactylus cf. schmidti (Lacertidae); Anolis spp., except A. auratus

273 (Dactyloidae; Fig. 3C); Hoplocercus spinosus (Hoplocercidae; Fig. 2B); Mabuya nigropunctata,

274 Mabuya sp. 2 (Scincidae); Riama striata, Tretioscincus bifasciatus (Gymnophthalmidae; Fig.

275 2C); Stenocercus trachycephalus (Tropiduridae; Fig. 3A); and Tarentola mauritanica

276 (Phyllodactylidae). When the two elements are joined by connective tissue, the lateral end of the

277 columella is cartilaginous. This condition was observed in Anolis antonii, A. chrysolepis, A.

278 fuscoauratus, A. maculiventris, A. trachyderma (Dactyloidae); Hoplocercus spinosus

279 (Hoplocercidae; Fig. 2B); Mabuya nigropunctata and Mabuya sp. 2 (Scincidae). When the

280 connective tissue is surrounding the columella-extracolumella joint, the cartilaginous shaft of the

281 columella is hidden. This formation of joint and connective tissue was observed in

282 Acanthocercus atricollis (Agamidae); Acanthodactylus cf. schmidti (Lacertidae); Anolis

283 tolimensis (Dactyloidae); Riama striata, Tretioscincus bifasciatus (Gymnophthalmidae; Fig. 2C);

284 Stenocercus trachycephalus (Tropiduridae); and Tarentola mauritanica (Phyllodactylidae). The

285 remaining specimens do not show connective tissue (Fig. 2A, 3B). The specimens of Anolis

286 mariarum and $A$. ventrimaculatus exhibit variation in the presence of the connective tissue. In

287 specimens ICN 5808 and MHUA 10014 of $A$. mariarum the connective tissue is seen between

288 the joint, while specimen MHUA 10013 does not have connective tissue; and in $A$.

289 ventrimaculatus, the specimens MHUA 10671 and MHUA 10672 display the connective tissue

290 between the joint, while in specimen PUJ 338 connective tissue is absent. 
292 Extracolumella. Usually, this element is cartilaginous, and composed of a small shaft, two to 293 four processes attached to the tympanic membrane, and the internal process (Fig. 1B) which is 294 present only in iguanians and related species. The extracolumella was present in all the 295 specimens examined and exhibits large morphological disparity among lizards. The variation in 296 this element involves the presence/absence of the anterior and/or posterior process, the shape of 297 the four processes, and the presence/absence of the internal process. The extracolumella variation 298 observed in the examined specimens is summarized in Table 3.

299 In the specimens studied, the extracolumella exhibits four processes - superior and inferior 300 pars, and the anterior and posterior processes - all attached to the tympanic membrane (Fig. 1B). 301 The pars superior and the pars inferior form the vertical axis of the extracolumella, and from this 302 axis, the anterior and posterior processes arise laterally. The variation observed in this pattern is 303 the lack of the anterior process in some species, or the lack of both processes (anterior and 304 posterior) in others. The general pattern (the presence of four processes of the extracolumella; 305 Fig. 1B), was observed in the specimens of Acanthocercus atricollis, Leiolepis belliana 306 (Agamidae); Acanthodactylus cf. schmidti (Lacertidae); Anolis spp. (Dactyloidae); Hemidactylus 307 brasilianus, Phelsuma madagascariensis (Gekkonidae; Fig. 4A); Tarentola mauritanica, 308 Thecadactylus rapicauda (Phyllodactylidae; Fig. 4B); Lialis jicari (Pygopodidae; Fig. 4C);

309 Gonatodes albogularis, G. concinnatus (Sphaerodactylidae; Fig. 5A); Hoplocercus spinosus, 310 Morunasaurus groi (Hoplocercidae; Fig. 5B); Stenocercus erythrogaster, S. trachycephalus, and

311 Tropidurus pinima (Tropiduridae; Fig. 5C). The anterior process is absent in Anadia bogotensis,

312 Gelanesaurus cochranae (Fig. 6A), Loxopholis rugiceps, Neusticurus medemi, Pholidobolus

313 montium, P. vertebralis, Riama striata, Tretioscincus bifasciatus (Gymnophthalmidae);

314 Stellagama stellio (Agamidae; Fig. 6B); Cnemidophorus lemniscatus (Teiidae); and Mabuya spp. 
315 (Scincidae; Fig. 6C). The posterior process is absent in Cnemidophorus lemniscatus (Teiidae); 316 Loxopholis rugiceps, Pholidobolus vertebralis (Gymnophthalmidae); Mabuya spp. (Scincidae;

317 Fig. 6C); and Stellagama stellio (Agamidae; Fig. 6B).

318 All four extracolumellar processes display some morphological variation in their shape. The 319 pars superior shows two principal variations, determined by the presence of an extension of the 320 upper edge, which varies in the orientation of the extension (anterior or posterior). The upper 321 edge of the pars superior has one posterior extension in the gekkotans Gonatodes albogularis, $G$. 322 concinnatus (Fig. 5A), Hemidactylus brasilianus, Lialis jicari (Fig. 4C), Phelsuma

323

324

327 328

331

333

334 335 336 337

madagascariensis (Fig. 4A), Tarentola mauritanica, and Thecadactylus rapicauda (Fig. 4B);

while in Tropidurus pinima (Tropiduridae), the extension is anterior (Fig. 5C). In all of these species, the distal end of the posterior extension of the pars superior is curved downward, except in Lialis jicari (Fig. 4C) in which this distal end is slightly straight, like the anterior extension in Tropidurus pinima (Fig. 5C). The remaining species lack any of these extensions. Additionally, the upper edge of the pars superior displays three kinds of surfaces: a slightly plane edge (Fig. 4A-C; 5A, C; 6A), a rounded edge (Fig. 5B; 6B), and an edge with small peaks (Fig. 6C). The upper edge is slightly plane in Acanthocercus atricollis, Leiolepis belliana (Agamidae); Acanthodactylus cf. schmidti (Lacertidae); Anadia bogotensis, Gelanesaurus cochranae (Fig. 6A), Loxopholis rugiceps, Neusticurus medemi, Pholidobolus montium, P. vertebralis, Riama striata, Tretioscincus bifasciatus (Gymnophthalmidae); Anolis spp. (Dactyloidae); Cnemidophorus lemniscatus (Teiidae); Gonatodes albogularis, G. concinnatus (Sphaerodactylidae; Fig. 5A); Hemidactylus brasilianus, Phelsuma madagascariensis (Gekkonidae; Fig. 4A); Lialis jicari (Pygopodidae; Fig. 4C); Stenocercus erythrogaster, S. trachycephalus, Tropidurus pinima (Tropiduridae; Fig. 5C); Tarentola mauritanica and 
338 Thecadactylus rapicauda (Phyllodactylidae; Fig. 4B); while the edge is rounded in Stellagama

339 stellio (Agamidae; Fig. 6B); Hoplocercus spinosus and Morunasaurus groi (Hoplocercidae; Fig.

340 5B). Finally, an edge with three small peaks is observed in the specimens of Mabuya spp.

341 (Scincidae; Fig. 6C).

342 The pars inferior is the extracolumellar process with the most conservative morphology. This

343 process displays an inverted triangular shape, with the thicker portion contacting the pars

344 superior (Fig. 1B), and the thinner portion at the distal end. The only variation observed is in the

345 distal end which can appear sharp or thick. The sharp distal end (Fig. 1B) is present in all the

346 specimens studied except in Gonatodes albogularis, G. concinnatus (Sphaerodactylidae; Fig.

347 5A); Hemidactylus brasilianus (Gekkonidae); and Thecadactylus rapicauda (Phyllodactylidae;

348 Fig. 4b) which shows a thick distal end with small projections on the pars inferior.

349 Both processes, anterior and posterior, arise from the superior half of the vertical axis of the

350 extracolumella, which is formed by the pars superior and inferior (Fig. 1B). Usually, the

351 processes are thin and extended laterally, but in some species, these are thick and/or turned

352 downward (see below). The anterior process appears in three main shapes: short (Fig. 3C), long

353 and pointed (Fig. 4C; 5B-C), or long with some small and sharp projections (Fig. 4A-B). The

354 first type, a short and pointed anterior process, is the simplest morphology for this process and

355 was observed in the studied specimens of Anolis spp. (Fig. 3C), except A. ventrimaculatus

356 (Dactyloidae) which shows a short process, but its distal end has two small pointed prolongations

357 (see below). The second type, a long and pointed process, was observed in Acanthocercus

358 atricollis, Leiolepis belliana (Agamidae); Acanthodactylus cf. schmidti (Lacertidae);

359 Hoplocercus spinosus, Morunasaurus groi (Hoplocercidae; Fig. 5B); Lialis jicari (Pygopodidae;

360 Fig. 4C); Stenocercus erythrogaster, S. trachycephalus, and Tropidurus pinima (Tropiduridae; 
361 Fig. 5C). In Lialis jicari (Fig. 4C), the anterior process is oriented downward, while in the other 362 species this process is straight. The third type, a long thick extension with some small and sharp 363 prolongations (Fig. 4A-B) was observed in Hemidactylus brasilianus and Phelsuma

364 madagascariensis (Gekkonidae; Fig. 4A); Tarentola mauritanica and Thecadactylus rapicauda 365 (Phyllodactylidae; Fig. 4B). Unlike the previous species, Gonatodes albogularis and G.

366 concinnatus (Sphaerodactylidae; Fig. 5A) present short anterior processes with the distal ends 367 turning downward, simulating a hook that is rounded in G. albogularis, while it forms a right 368 angle in G. concinnatus (Fig. 5A). There is no anterior process in the specimens of Anadia 369 bogotensis, Gelanesaurus cochranae (Fig. 6A), Loxopholis rugiceps, Nesticurus medemi, Riama 370 striata, Tretioscincus bifasciatus (Gymnophthalmidae); Cnemidophorus lemniscatus (Teiidae);

371 all specimens of Mabuya spp. (Scincidae; Fig. 6C); or Stellagama stellio (Agamidae; Fig. 6B).

372 The posterior process shows a slight variation in both the length and thickness of its extension.

373 Among the specimens studied, most of them show an extended and thin, or a short and acute 374 process, except for Lialis jicari (Pygopodidae) which shows a short thick posterior process 375 turned upward, simulating a hook (Fig. 4C). The extended thin posterior process was observed in 376 Acanthocercus atricollis (Agamidae); Anolis ventrimaculatus (Dactyloidae); Hoplocercus 377 spinosus (Hoplocercidae); Nesticurus medemi (Gymnophthalmidae); Phelsuma 378 madagascariensis (Gekkonidae; Fig. 4A); Stenocercus erythrogaster, S. trachycephalus, 379 Tropidurus pinima (Tropiduridae; Fig. 5C); Tarentola mauritanica and Thecadactylus rapicauda 380 (Phyllodactylidae; Fig. 4B); while the short and acute posterior process was observed in 381 Acanthodactylus cf. schmidti (Lacertidae); Anadia bogotensis, Gelenasaurus cochranae (Fig. 382 6A), Pholidobolus montium, Riama striata, Tretioscincus bifasciatus (Gymnophthalmidae); 383 Anolis spp., except A. ventrimaculatus (Dactyloidae); Gonatodes albogularis, G. concinnatus 
384 (Sphaerodactylidae; Fig. 5A); Hemidactylus brasilianus (Gekkonidae); Leiolepis belliana 385 (Agamidae); and Morunasaurus groi (Hoplocercidae; Fig. 5B). The specimens of 386 Cnemidophorus lemniscatus (Teiidae); Loxopholis rugiceps (Gymnophthalmidae); Mabuya spp. 387 (Scincidae; Fig. 6C); and Stellagama stellio (Agamidae; Fig. 6B) do not show the posterior 388 process.

389 In some specimens, the extracolumella, usually cartilaginous, exhibits a red-stained region of 390 different sizes and in different degrees of staining, in the central axis, and the lateral processes, 391 indicating the presence of osseous tissue. This feature was observed in Acanthocercus atricollis, 392 Leiolepis belliana, Stellagama stellio (Agamidae; Fig. 6B); Anolis spp. (Dactyloidae; Fig. 3C); 393 Hemidactylus brasilianus (Gekkonidae); Morunasaurus groi (Hoplocercidae; Fig. 5B);

394 Stenocercus trachycephalus (Tropiduridae; Fig. 3A); and Thecadactylus rapicauda 395 (Phyllodactylidae; Fig. 4B). This feature is particularly noticeable in some specimens of the 396 Anolis species in which the red-stained area appears bigger and more intense than in the other 397 species.

398 Internal process. This process originates from the shaft of the extracolumella and extends 399 laterally to contact the tympanic conch of the quadrate bone. It is fan-shaped, and has a thin 400 origin at the shaft of the extracolumella shaft, but expands distally to develop a broad edge. This 401 process was only found in Acanthocercus atricollis, Leiolepis belliana, Stellagama stellio 402 (Agamidae); Acanthodactylus cf. schmidti (Lacertidae); Anolis spp. (Dactyloidae; Fig. 3C); 403 Cnemidophorus lemniscatus (Teiidae); Hoplocercus spinosus, Morunasaurus groi 404 (Hoplocercidae; Fig. 5B); and Stenocercus erythrogaster, S. trachycephalus, and Tropidurus 405 pinima (Tropiduridae; Fig. 5C). This process is absent in the remaining studied species. 
406 The internal process varies in the width of the origin at the junction with the extracolumella. The 407 internal process is triangular with a thin origin and a very differentiated distal edge in L. belliana, 408 A. cf. schmidti, and T. pinima (Fig. 5C), while in other species, the origin is broad (e.g., $A$. 409 atricollis, S. stellio; Anolis spp., H. spinosus, M. groi; and S. trachycephalus). Although in the 410 specimens studied of C. lemniscatus and S. erythrogaster, the internal process was evident, it 411 was not possible to determine the size of its origin due to mechanical damage caused by 412 inadequate specimen preparation.

413

414 Ancestral Reconstruction

415 Definition of characters: Based on the morphological descriptions presented above, the 416 following middle ear characters were defined to analyze them in a phylogenetic framework. 417 Despite the limited sampling, the results of this survey provide a baseline to understand overall 418 variation and outline a general scenario about the evolutionary changes of selected features of the 419 middle ear in lizards.

420 - Character 1. Length of the columella relative to the extracolumella central axis length. [0] equal 421 length (Fig. 2C); [1] longer (Fig. 3A); and [2] shorter (Fig. 3B).

422 - Character 2. Extracolumella. [0] simple (Fig. 4A); [1] complex; [2] elongated; [3] absent. To 423 test if there is a general pattern in the reduction of the extracolumellar processes, we summarized 424 the available information on this structure into four states, including the absence of the 425 extracolumella. The state [0] refers to the extracolumellas that have at least three processes 426 regardless of the size of each, while the state [1] indicates the extracolumellas with the four 427 developed processes - the superior and inferior pars, and the anterior and posterior processes. 428 Finally, an elongated extracolumella refers to a case where this structure runs anteriorly along 
429 the quadrate and mandible and contacts the skin; this kind of extracolumella does not show any 430 processes.

431 - Character 3. Nature of the Internal Process. [0] Absent (Fig. 2A); [1] present (Fig. 2B).

432 Character mapping: Characters were optimized using parsimony with unordered states and 433 equal weights, and Bayesian analyses with the all rates different (ARD) and the equal rates (ER) 434 models. The summaries of the optimization of characters with parsimony are presented in 435 Figures 7 and 8, and the values of the posterior probabilities of the Bayesian reconstructions in 436 Table 5. The complete mapping with parsimony (Fig. S1) and Bayesian reconstructions (Fig. S2437 S4), and the posterior probability values (Table S3) are also available on Morphobank (O'Leary 438 \& Kaufman, 2012) - Project 3551 http://morphobank.org/permalink/?P3551

439 Character 1. Length of the columella relative to the extracolumella central axis length.

440 The parsimony approach (Fig. 7; Fig. S1) shows the ancestral condition of the columella's length

441 relative to the extracolumella central axis length for Squamata [node 2] as ambiguous between

442 the states shorter and longer. Also, there is ambiguity between the three states of the character for 443 the ancestor of Teiioidea [27], and between the states longer and equal length in Lacertoidea 444 [26], Lacertidae [39], (Amphisbaenidae + Lacertidae) [33]. The shorter columella state was the 445 reconstructed state for the ancestral node of Gekkota [4] and Pygopodidae [7]; and the longer 446 columella state for the nodes of (Xantusiidae (Gerrhosauridae + Cordylidae)) [19], Scincoidea 447 [18], Anguimorpha [43], Agamidae [55], Acrodonta [51], Phrynosomatidae [73], Pleurodonta 448 [60], Iguania [50] (Anguimorpha + Iguania) [42], (Lacertoidea (Serpentes (Anguimorpha + 449 Iguania))) [25], (Scincoidea (Lacertoidea (Serpentes (Anguimorpha + Iguania)))) [17]. There is 450 no available information for the clades Amphisbaenia [34], (Amphisbaenidae + Trogonophidae) 451 [38], in (Bipedidae ((Cadeidae + Blanidae) (Amphisbaenidae + Trogonophidae)) ) [35]. 
452 The Bayesian analysis (Table 5; Fig. S2; Table S3) with both models shows ambiguity for the 453 ancestral node of Squamata [2] with equal probabilities for all states. The ARD reconstruction 454 found ambiguity for all other clades with similar values for each state. However, the higher 455 support values for these clades are for the longer columella. Similarly, the ER reconstruction 456 found ambiguity for all clades with equal values of probability for each character state for all 457 these clades.

458 Character 2. Extracolumella. The parsimony approach (Fig. 8A, Fig. S1) defines the simple 459 extracolumella as the ancestral condition for Squamata [node 2]. This state was also 460 reconstructed for the nodes of the clades Scincoidea [18], Teiioidea [27], Lacertidae [39], 461 Amphisbaenia [34], (Amphisbaenidae + Lacertidae) [33], Lacertoidea [26], Anguimorpha [43], 462 Agamidae [55], Acrodonta [51], Iguania [50], (Anguimorpha + Iguania) [42], and (Lacertoidea 463 (Serpentes (Anguimorpha + Iguania)) [25], (Scincoidea (Lacertoidea (Serpentes (Anguimorpha 464 + Iguania)))) [17]. The complex extracolumella was the estimated ancestral state in Gekkota [4], 465 Pygopodidae [7], and Phrynosomatidae [73]; the elongated extracolumella in (Amphisbaenidae + 466 Trogonophidae) [38]; and the absence of extracolumella in (Bipedidae ((Cadeidae + Blanidae) 467 (Amphisbaenidae + Trogonophidae))) [35]. This reconstruction showed an ambiguous state 468 result for the ancestral nodes of the clades (Xantusiidae (Gerrhosauridae + Cordylidae)) [19], and 469 Pleurodonta [60].

470 There was no conflict between the parsimony method and both models of the Bayesian 471 approach (Table, 5; Fig. S3; Table S3) used to reconstruct the ancestral state of Squamata [2] 472 since the Bayesian analyses show a greater certainty for the simple extracolumella as the 473 ancestral state (Table 5) although also show a minimum probability for the complex state. The 474 ARD model reconstruction mostly agrees with the parsimony results except for the following 
475 exceptions. At the nodes for Gekkota [4], Pleurodonta [60], Pygopodidae [7], and

476 Phrynosomatidae [73], the higher probability for the ancestral state is for the complex

477 extracolumella, and for the first three clades (Gekkota [4], Pleurodonta [60], and Pygopodidae

478 [7]) the lower probability is for the absence of it. The ancestral node of Phrynosomatidae [73]

479 shows lower and similar probabilities for the simple columella and its absence. The ancestral

480 node for the family Lacertidae shows a higher probability for the simple extracolumella and a

481 lower probability for the complex one. At the ancestral nodes of (Amphisbaenidae +

482 Trogonophidae) [38], and (Bipedidae ((Cadeidae + Blanidae) (Amphisbaenidae +

483 Trogonophidae))) [35] there is great certainty for the elongated extracolumella state, as the

484 probabilities are very low values for other states. The clade (Xantusiidae (Gerrhosauridae +

485 Cordylidae)) [19] shows a high probability for the simple state and a lower probability for the 486 complex state.

487 The ER model reconstruction mostly agrees with the parsimony results but shows the 488 following differences (Table 5). In the ancestral node for Phrynosomatidae [73] there is a high 489 probability for the complex columella state and a lower one for a simple columella; the ancestral 490 node of (Amphisbaenidae + Trogonophidae) [38] has a major probability for the elongated state 491 compared to a lower likelihood for the absent condition, but at the node for (Bipedidae 492 ((Cadeidae + Blanidae)(Amphisbaenidae + Trogonophidae))) [35] the higher probability is the 493 absence of extracolumella with lower values for the elongated and simple state. For the ancestral 494 node of Pleurodonta, there is a greater certainty for the complex extracolumella; and for 495 (Xantusiidae (Gerrhosauridae + Cordylidae)) [19] the higher value is for the simple state and the 496 lower for the complex one. With the reconstruction of the ARD model, the ancestral node 
497 estimate for the family Lacertidae shows a higher probability for the simple extracolumella and a 498 lower probability for the complex one.

499 Character 3. Nature of the Internal Process. The parsimony reconstructions (Fig. 8B; Fig. 500 S1) estimated the ancestral condition for Squamata [2] is the absence of internal process, which 501 was also the reconstructed state for Gekkota [4] and Gymnophthalmidae [30]; while the 502 evolutionary novelty, the presence of the process, was reconstructed in the ancestral nodes for 503 Teiioidea [27], Lacertoidea [26], Anguimorpha [43], (Anguimorpha + Iguania) [42], Iguania 504 [50], (Lacertoidea (Serpentes (Anguimorpha + Iguania))) [25], Anguidae [47], Acrodonta [51], 505 Pleurodonta [60], and Phrynosomatidae [73]. This reconstruction shows as ambiguous states the 506 ancestral nodes of the clades Scincoidea [18], (Xantusiidae (Gerrhosauridae + Cordylidae)) [19], 507 Xantusiidae [20], (Scincoidea (Lacertoidea (Serpentes (Anguimorpha + Iguania)))) [17], and 508 (Alopoglossidae + Gymnophthalmidae) [29]. The character is not applicable for amphisbaenians. 509 Contrary to the parsimony results, the reconstructions obtained for this character using the 510 ARD (Table 5; Fig. S4; Table S3); model defined the presence of the internal process as the 511 ancestral state of Squamata [2] with great certainty, while for the ER model (Table 5; Fig. S4; 512 Table S3) it remains ambiguous, showing similar probabilities for both states (Table 5). The 513 ARD model reconstruction mostly agrees with the parsimony results but shows the following 514 exceptions. The presence of an internal process has a high probability in the reconstruction of the 515 nodes of Scincoidea [18], (Xantusiidae (Gerrhosauridae + Cordylidae)) [19], Xantusiidae [20]; 516 (Scincoidea (Lacertoidea (Serpentes (Anguimorpha + Iguania)))) [17]. This reconstruction 517 results in ambiguous state estimations for the ancestral node of Gymnophthalmidae [30] with a 518 higher probability for the absence than the presence of the internal process, while in 519 (Alopoglossidae + Gymnophthalmidae) [29], the higher probability is for the presence. In the 
520 amphisbaenian clade [34], the highest likelihood is for the presence of the process and a lower

521 probability for the inapplicability of the character, while the clades (Amphisbaenidae +

522 Trogonophidae) [38], and ((Bipedidae ((Cadeidae + Blanidae) (Amphisbaenidae +

523 Trogonophidae)) [35] show the contrary.

524 There are a few differences between the reconstructions obtained with the ER model (Table 5;

525 Fig. S4) and the parsimony analysis (Fig. 8B; Fig. S1). The ER model found a higher probability

526 for the presence of the process in the ancestral node of the clades Teiioidea [27] and

527 Gymnophthalmidae [30]. For the nodes of the clades where the character is not applicable, the

528 ER model found a higher probability for the presence of the process in the ancestor of

529 amphisbaenians [34], contrary to the values found for the ancestral node of (Amphisbaenidae +

530 Trogonophidae) [38] and (Bipedidae ((Cadeidae + Blanidae) (Amphisbaenidae +

531 Trogonophidae))) [35]. The ancestral nodes of the clades (Amphisbaenidae + Lacertidae) [33],

532 Lacertoidea [26], and Pygopodidae [7] show lower probabilities for the inapplicability of the

533 character, with a higher probability for the presence of the process in the two first clades and the

534 absence in the last one. The ER model analysis found a higher probability for the presence of the

535 process in the ancestral nodes of the clades Xantusiidae [20], (Xantusiidae (Gerrhosauridae +

536 Cordylidae) [19], Scincoidea [18], (Alopoglossidae + Gymnophthalmidae) [29], (Scincoidea

537 (Lacertoidea (Serpentes (Anguimorpha + Iguania)))) [17], that were defined as ambiguous by the 538 parsimony approach.

539

540 Discussion

541 Although there is a lot of information available about the skull of lizards, most of these

542 publications provide incomplete information about the middle ear, being limited to only a few 
543 details of the columella and even less about the extracolumella. The main studies regarding the

544 middle ear as an anatomical complex, were realized by Versluys (1898) and Wever $(1973,1978)$.

545 These authors described morphological details of each structure for many species within a

546 comparative framework that has allowed the establishment of morphological patterns of the

547 middle ear of lizards. This study adds detailed information about the middle ear morphology and

548 variation in lizard, revealing an important source of variation previously understudied.

549 In general, lizards have a middle ear formed by a columella, and an extracolumella (which

550 shows an internal process in some groups), with the later structure displaying large

551 morphological variation (Wever, 1978). Some species show extreme modifications or reductions

552 of the middle ear (e.g., Blanus and Bipes, Wever \& Gans, 1973; Wever, 1978; Chamaeleo,

553 Wever, 1968; and Rhampholeon, Toerien, 1963), or even the total absence of it (e.g., Aprasia

554 spp., Baird, 1970; Wever, 1978; Daza \& Bauer, 2015).

555 Columella. The typical pattern of the middle ear in lizards shows a quite conservative columella

556 (Wever, 1978). However, in some cases, it is complicated to compare the scarce variation that it

557 presents, due to the terminology used to describe this structure in the published descriptions.

558 The presence of the stapedial foramen (Fig. 2A) is accepted as a primitive condition in 559 reptiles (Goodrich, 1958; Underwood, 1957; Greer, 1976; Estes, de Queiroz \& Gauthier, 1988;

560 Gauthier, Estes \& de Queiroz, 1988). The only living lepidosaurs that exhibit this foramen are 561 Anelytropsis, Dibamus, and some gekkotans (Kamal, 1961; Greer, 1976; Rieppel, 1984; Estes, de

562 Queiroz \& Gauthier, 1988; Gauthier, Estes \& de Queiroz, 1988; Bauer, 1990). Although this

563 foramen may be present in embryos of amphisbaenians, it is always absent in the adults

564 (Versluys, 1898; Gans, 1978; Kearney, 2003). In gekkotans the foramen has been recorded in all

565 genera of Sphaerodactylidae (Bauer et al., 2018), and some representatives of Eublepharidae 
566 (Posner \& Chiason, 1966), Gekkonidae (Kluge \& Eckardt, 1969; Bauer, 1990; Daza, Aurich \& 567 Bauer, 2012; Villa et al., 2018), and Phyllodactylidae (Daza et al., 2017; Villa et al., 2018). As

568 expected, we recorded the presence of the stapedial foramen in all the gekkotans examined

569 (Table 2), confirming its presence in Gonatodes (Sphaerodactylidae), Hemidactylus and

570 Phelsuma (Gekkonidae), and Tarentola mauritanica (Phyllodactylidae), as previously registered

571 by Villa et al. (2018) in this last species. We also confirmed the absence of the stapedial foramen

572 in Lialis (Pygopodidae) and Thecadactylus (Phyllodactylidae), as was previously recorded by

573 Kluge \& Nussbaum (1995) and Wever (1974) for these genera. The absence of the stapedial

574 foramen has also been recorded in several genera of Gekkonidae, such as Christinus (Bauer,

575 Good \& Branch, 1997), Ebenavia, Gehyra, Gekko, and Paroedura (Kluge \& Nussbaum, 1995);

576 and both states have been described in the genus Homonota (Phyllodactylidae) - the absence by

577 Kluge \& Nussbaum (1995), and the presence by Daza et al. (2017).

578 There are some relative differences in the size of the rod and footplate of the columella in

579 lizards. According to Wever (1978), the rod is usually slender and flexible, although in a few

580 species it is thick and sturdy; and the footplate is mostly broadly flared, while a rounded knob

581 footplate, a little larger than the rod itself, is present in just a few instances (Wever, 1978). Evans

582 (2008) describes the sizes of the rod and footplate and its variation using the more common

583 morphological pattern (referred to as the "normal" pattern) as a point of comparison: a slender

584 rod with a small footplate, typical pattern exhibit by iguanians. Thus, according to Evans (2008),

585 the columellar rod is: "normal" in iguanians, gekkotans, and scincids; shorter and usually with an

586 expanded footplate, as in Anguis, Saurodactylus, Xenosaurus (Rieppel, 1980, Fig. 21),

587 Agamidae, and Dibamidae; or longer, as in Shinisaurus. It can also vary from long to short

588 within the same genus, as in Ceratophora (Pethiyagoda \& Manamendra-Arachchi, 1998), or 
589 show tendencies towards the reduction of the rod and enlargement of the footplate, as observed

590 in gymnophthalmids (Evans, 2008). In some of the previously published morphological

591 descriptions, there are a few specific remarks made regarding the size of the columellar rod, such

592 as noting the extremely short length in amphisbaenians (Wever \& Gans, 1973), and the agamid

593 Ceratophora (Pethiya \& Manamendra-Arachchi, 1998). Substantial differences in the increased

594 size of the footplate have been frequently described, for example: the expanded stapedial

595 footplate of amphisbaenians and anniellids (Baird, 1970; Wever \& Gans, 1973), the noticeable

596 asymmetrical footplate of Draco volans (Wever, 1978), and the large footplates of Anniella

597 pulchra, Cophosaurus texanus (Wever, 1973), Ceratophora stoddartii (Wever, 1978), and

598 Rhineura floridana (Baird, 1970; Olson, 1966). Most of the specimens examined in this study

599 exhibit a slender columellar rod with a proportionally small footplate, except in the case of Lialis

600 jicari (Fig. 3B) which shows an evident short, but not stout, rod with a small footplate. This

601 description differs from that of L. burtonis by Wever (1974), who described a short and sturdy

602 columella with a relatively large footplate. In this case, according to the figure of the middle ear

603 of L. burtonis (Wever, 1974, Fig. 4), it is possible to assume that there are no significant

604 differences between the columella of L. jicari and L. burtonis, except in the references used to

605 describe their sizes. It is difficult to compare the morphology of the columella between species

606 due to the different parameters and criteria used by each author to estimate the size of the

607 structures. For this reason, we chose to define a ratio between the size of the columella and one

608 of its associated structures. Thus, given the functional role of the complex formed by the

609 columella and extracolumella pointed out by Wever (1978), we used the ratio between the

610 relative length of the columellar rod and the length of the central axis of the extracolumella (Fig.

611 1, 2C, 3A-B), previously defined as ANC - "total anchorage length" by Werner \& Igic (2002). 
612 Using our observations and some illustrations available in the literature (see Table 4), we were

613 able to estimate the different conditions of this feature in some species. We are aware that

614 gathering information on this feature without precise measures, as well as estimating the

615 measures from published illustrations is not the most accurate method; however, this provides

616 some assessment regarding the existing variation in this ratio and affords a preliminary

617 estimation of the evolutionary history of variation in this feature. Based on the current

618 information available, there is no phylogenetic signal to the variation of the columella-

619 extracolumella ratio we observed in the major groups of lizards, since the parsimony-based

620 ancestral state reconstruction shows multiple independent appearances of all three states of this

621 character in less inclusive groups, and the Bayesian approach found similar probabilities for each

622 state at all ancestral nodes (Fig. 7; Table 5).

623 The expanded distal end of the osseous columella (Fig. 3) is not explicitly mentioned in the

624 available descriptions of the lizard columella; however, Wever (1978) described and illustrated a 625 thin, delicate, and rather flexible mid-portion in the columella of Trachylepis brevicollis $(=$ 626 Mabuya brevicollis) that was also illustrated in other species, such as Crotaphytus collaris,

627 Callisaurus draconoides, Holbrookia maculata, and Sceloporus magister (Wever, 1978). These

628 records make evident the observation of a widening of the distal end of the columella in these

629 species, a feature that we also registered in some species (see Table 2). Werner \& Igic (2002)

630 measured different elements of the middle ear to establish the effects of the dimensions of these

631 structures on the auditory sensitivity of gekkonid lizards. Their results suggest that part of the

632 sensitivity in these lizards would depend on the sizes of the structures of the middle ear. The

633 columella measures used in that study were: the length of the columella and its diameter in the

634 midpoint, and the diameter of the footplate (Werner \& Igic, 2002, Fig. 1). Thus, the presence 
635 (Fig. 3) or absence of a widening in the distal end of the columella could also be related to

636 auditory sensitivity. However, our observations show the existence of both states of this feature

637 (presence and absence of the widening) in Anadia bogotensis, implying this trait displays

638 individual variation, and hence we flag the necessity of evaluating this feature across a larger

639 sample of individuals.

640 According to Wever (1978), in some species, the cartilaginous joint between columella and

641 extracolumella shows a discontinuity comprised of dense connective tissue that gives rigidity to

642 this point, and that can surround the joint, or occur between both structures. Apparently however,

643 the only specific record of this feature was made by Wever (1978) mentioning the absence of this

644 kind of joint in Trachylepis brevicollis (= Mabuya brevicollis). In our study, both the presence

645 and absence of the connective tissue in this joint were observed in different groups and families

646 (Table 2), and even in the same species, Anolis marianum, which suggests this feature possibly

647 displays intraspecific variation. With the current data, we cannot address the amount of variation,

648 thus it is necessary to examine more specimens of Anolis marianum to establish if it could be due

649 to ontogenetic variation or a polymorphism that could support the presence of cryptic species.

650 We also suggest making an in-depth exam using more detailed sampling methods, such as

651 histological techniques, to confirm the kind of tissue involved and determine its definite

652 association with both the columella and the extracolumella.

653

654 Extracolumella. Several descriptions and illustrations of the extracolumella exist, which present

655 accurate and detailed information and show significant morphological variation of this structure

656 (e.g., Versluys, 1898; Peterson, 1966; Posner \& Chiason, 1966; Wever, 1968; \& Wever \&

657 Werner, 1970, 1972; Wever, 1973, 1978; Werner et al., 2005). Some variations of the 
658 extracolumella are relatively rare, such as the extreme reduction observed in Varanus

659 bengalensis (Varanidae, McDowell, 1967); a distinct rough oval form in Lanthanotus borneensis

660 (Lanthanotidae, McDowell, 1967); a short structure with a dense mass of ligamentous fibers that 661 split into two branches, one extending along the lower jaw, and the other along the upper jaw in 662 Rhineura floridana (Rhineuridae, Wever, 1978); and an elongated structure that extends along 663 the quadrate and laterally connects with the labial skin in Amphisbaenidae and Trogophidae, 664 (Versluys, 1898; Wever \& Gans, 1973; Kearney, 2003; Kearney, Maisano \& Rowe, 2005). The 665 absence of the extracolumella in lizards has only been registered in the species of Aprasia 666 (Pygopodidae, Wever, 1978), Bipes (Bipedidae, Wever \& Gans, 1973), and Blanus (Blanidae, 667 Wever \& Gans, 1973). On the other hand, the more common morphological pattern found in 668 lizards is an extracolumella with four principal processes. Some of the variation described for 669 this element refers to the size or lack of one or more of these processes. In most species, all these 670 processes are easily distinguished, but in a few cases, as in Ceratophora stoddartii (Agamidae) 671 and Chamaeleo (Chamaeleonidae), there is some uncertainty about a processes' presence and 672 equivalences (Wever, 1973, 1978).

673 The four extracolumellar processes have been either described or illustrated in Callisaurus 674 (Phrynosomatidae); Coleonyx variegatus and Eublepharis macularius (Eublepharidae), 675 Chondrodactylus bibronii (=Pachydactylus bibronii) and Gekko gecko (=Gekko verticillatus) 676 (Gekkonidae); Crotaphytus collaris_(Crotaphytidae); Iguana iguana (= Iguana tuberculata) 677 (Iguanidae); and Lialis burtonis (Pygopodidae) (Versluys, 1898; Iordansky, 1968; Posner \& 678 Chiason, 1966; Werner \& Wever, 1972; Wever, 1974, 1978; Werner et al., 2005). In this study, 679 we found these four processes to be present in Agamidae, Dactyloidae, Hoplocercidae, 680 Lacertidae, Phyllodactylidae, Sphaerodactylidae, and Tropiduridae, and in two additional species 
681 of Gekkonidae and one of Pygopodidae (Table 3). In all these cases, the pars superior and

682 inferior, and the anterior and posterior processes are evident and easily recognized. The presence

683 of the four processes registered here in the species of Gekkota agrees with the literature records

684 for this group, and we also add information on these features to the morphology previously

685 described in Agamidae and Lacertidae (see below).

686 The absence or extreme reduction of the pars superior only has been registered in Draco

687 volans and Phrynocephalus maculatus (Agamidae), and Cophosaurus texanus

688 (Phrynosomatidae) (Wever, 1973, 1978), and there are no records indicating the absence of the

689 pars inferior in any of the lizard groups. In contrast, the lack of the anterior, posterior, or both

690 processes are more frequent within some families and genera. In Gymnophthalmidae, the genera

691 - Anadia, Gelanesaurus, Neusticurus, Riama, and Tretioscincus do not have an anterior process

692 is absent; while Loxopholis lacks both processes (Table 3). In Teiidae, the genera - Pholidoscelis

693 lineolatus (= Ameiva lineolata), and Tupinambis teguixin (= T. nigropunctatus) do not have the

694 anterior process (Versluys, 1898; Wever, 1978), while Cnemidophorus lemniscatus lacks both

695 processes. In Lacertidae, there is no anterior process present in Timon lepidus (= Lacerta

696 ocellata) (Versluys, 1898), but we recorded the presence of a very short and thin anterior process

697 in Acanthodactylus cf. schmidti. The agamids Draco volans and Phrynocephalus maculatus do

698 not have any of these processes (Wever, 1973, 1978), and this feature corresponds to our

699 observations in Stellagama stellio, but differs from those in Acanthocercus atricollis and

700 Leiolepis belliana, species that exhibit all four extracolumellar processes. The variation in this

701 structure has also been described within some genera. According to Earle (1961a; 1961b), the

702 genera Callisaurus and Holbrookia (Phrynosomatidae) have four extracolumellar processes,

703 while Wever $(1973,1978)$ points out that C. draconoides and H. maculata do not have either the 
704 anterior nor the posterior processes. Furthermore, H. maculata also shows an extreme reduction

705 of the pars superior and inferior. Similarly, according to Wever (1973), and Han \& Young

706 (2016), Phrynosoma coronatum (Phrynosomatidae) and Varanus salvator (Varanidae) do not

707 present the anterior process; while Versluys (1898), McDowell (1967), and Wever (1973) stated

708 that $P$. platyrhinos, $V$. bengalensis, and $V$. niloticus do not exhibit either process. We observed

709 interspecific variation in Pholidobolus (Gymnophthalmidae), since P. montium does not have the

710 anterior process and $P$. vertebralis does not have either of them.

711 The absence of both processes, anterior and posterior, has been recorded in Anguis fragilis

712 and Anniella pulchra (Anguidae), and Trachylepis brevicollis (= Mabuya brevicollis) (Scincidae)

713 (Versluys, 1898; Wever, 1973, 1978). We found this condition in Cnemidophorus lemniscatus

714 (Teiidae) and the species of Mabuya (Scincidae). The absence of the posterior process, when the

715 anterior process is present, has only been reported in Heloderma suspectum (Helodermatidae)

716 and Xenosaurus grandis (Xenosauridae) (Versluys, 1898; Wever, 1973, 1978).

717 The available information about the shapes of the extracolumellar processes describes them as

718 pointed and long or short cartilaginous structures, without any further descriptive detail. There

719 are no specific descriptions of the shape of each extracolumellar process, except for a few

720 mentions and illustrations of the anterior process in some species of Gekkota (Versluys, 1898;

721 Posner \& Chiason, 1966; Werner \& Wever, 1972; Wever, 1978; Werner et al., 2005, 2008). In

722 the specimens available for this study, we found some differences in the shapes of the

723 extracolumellar processes, which illustrates wide variation in these structures. Although our

724 sample is not representative of all groups of lizards, it was enough to display such variation,

725 mainly in the pars superior and the anterior process. Thus, with the available information, the

726 pars superior, which shows noticeable variation in its shape (Table 3), characterizes the species 
727 of Gekkota with a posterior prolongation of its upper edge (Fig. 4A-C, 5A); while Hoplocercidae

728 (Fig. 5B, 6B) can be differentiated by a rounded upper edge; Scincidae (Fig. 6C) by a tridentate

729 upper edge; and Tropidurus pinima (Tropiduridae) by an anteriorly prolonged and shorter upper 730 edge (Fig. 5C).

731 Among the species studied which show an anterior process, the more frequently observed 732 shape is a pointed cartilaginous extension that can be short (Fig. 3C), or long (Fig. 4C, 5B-C), 733 which corresponds with the shape most commonly described in the literature. However, we 734 found that in the specimens of Gekkonidae and Phyllodactylidae examined (Table 3), the anterior 735 process is a long and thick extension with some small and sharp prolongations (Fig. 4A-B). This 736 shape has also been described or illustrated in Eublepharidae (Coleonyx variegatus, Eublepharis 737 macularius), and Gekkonidae (Chondrodactylus bibronii and Gekko gecko) (Versluys, 1898;

738 Posner \& Chiason, 1966; Werner \& Wever, 1972; Wever, 1978; Werner et al., 2005). The 739 remaining species of Gekkota examined (Table 3) did not show these sharp prolongations in the 740 anterior process. One example is Lialis jicari (Pygopodidae, Fig. 4C), which shows a long and 741 pointed process that is not oriented anteriorly, but downward; as well as the distal end of the 742 anterior process that turns downward in Gonatodes (Sphaerodactylidae, Fig. 5A).

743 The pars inferior and the posterior process are more morphologically conserved. The pars

744 inferior shows a sharp distal end in most of the species with available information, but a thicker

745 distal end in Gekkonidae, Phyllodactylidae, and Sphaerodactylidae (Table 3). In the posterior

746 process, the only variation observed was the overall size, except in Lialis jicari that shows both a

747 short and thick posterior process that turns upward resembling a hook (Fig. 4C). These features -

748 the shapes of the pars superior, the anterior process, and the shape of the distal end of the pars 
749 inferior - should be evaluated in greater detail and in a larger sample, to confirm if the variation

750 observed has any taxonomic relevance within Gekkota.

751

752 The internal process. The internal process is an additional extracolumellar structure that arises

753 close to the joint with the columella, running anteriorly to attach to the quadrate. The proposed

754 function of this process is mainly to protect the middle ear structures (Wever, 1978). The internal

755 process was very similar in all species studied. It is fan-shaped, and the main morphological

756 variation was the width of its origin at the shaft of the extracolumella. The shape of the process is

757 similar to the morphology described by Wever (1978) in Sceloporus magister

758 (Phrynosomatidae), Crotaphytus collaris (Crotaphytidae), Ameiva lineolata (= Pholidoscelis

759 lineolatus, Teiidae), and Agama agama (Agamidae), but it is not possible to compare the

760 extracolumellar origin of the process based on the Wever's descriptions. Wever (1978)

761 differentiated two internal process types based on an auditory experiment's results and the

762 process's flexibility and shape. The experiments consisted of measuring the columella sensitivity

763 to a range of tones with two different variations, the internal process attached to the quadrate (its

764 normal condition) and with this connection interrupted. Results on the experiments of C. collaris

765 were similar, showing a slight improvement in the responses to low tones and a slight decrease to

766 high ones. In C. collaris, it seems like the role of the internal process is protection instead to

767 participate in the hearing function. However, in other species such as the phrynosomatid

768 Callisaurus draconoides (Weber, 1978: Figs. 6-19 and 6-20) where the internal process less

769 flexible or it "consist of a substantial mound-like elevation that according (Weber, 1978: 158),

770 the results of the experiment showed some differences when the connection of the internal

771 process with the quadrate was interrupted. The sensitivity did not show major changes to low 
772 frequencies but showed a significant effect in losing the sensitivity to high frequencies,

773 suggesting that the internal process has an auditive function (Wever, 1978). According to this,

774 the morphology and the function of the internal process must be evaluated in more detail. Given

775 the great diversity of the groups that have an internal process, it is expected that there will be 776 significant variation among the groups.

777

778 The middle ear types in lizards. The three types of middle ear described by Wever \& Werner

779 (1970) represent the more common morphologies observed in lizards and show an important 780 morphological variation within each one. Despite the morphological differences between the 781 types, all of these are highly effective in sound reception and transmission (Wever, 1973).

782 According to Wever (1978), the most common type in lizards is the iguanid type that is present 783 in Iguanidae, Agamidae, Cordylidae, Gerrhosauridae, Helodermatidae, Lacertidae, Teiidae, 784 Varanidae, and Xantusiidae (see Wever, 1978, Table 5-III, p. 132). The species that Wever 785 (1978) originally included in Iguanidae now belong to the families Corytophanidae,

786 Crotaphytidae, Dactyloidae, Tropiduridae, Opluridae, Phrynosomatidae, and Iguanidae (see

787 Wever, 1978, p.215-216). In addition, in our work, we found this pattern in species from some of 788 these families and from Hoplocercidae (Table 3) that we add to the list. According to Wever \& 789 Werner (1970), the iguanid type is characterized by the presence of the internal process. To this, 790 we add that this type is further characterized by the presence of at least three well-defined 791 extracolumellar processes, since all species that exhibit the internal process also have these 792 additional processes. Given the variation observed in the shape and number of the 793 extracolumellar processes within the iguanid type, we suggest greater evaluation of these 794 characters within the families that possess them, in order to determine whether the variation in 
795 the morphology of these processes provides further systematic information at a finer taxonomic 796 scale.

797 The gekkonid middle ear type is only present in the families of Gekkota (Werner \& Wever, 798 1972; Wever, 1978). Although we did not have available material to check the presence of the 799 extracolumellar muscle in any specimen within our sample, we recorded that none of the species 800 of Gekkota studied showed internal processes. Additionally, all the specimens from these 801 families exhibited: i) four extracolumellar processes, ii) a posterior extension in the pars 802 superior, and iii) an anterior process with some small and sharp projections. Thus, we add these 803 three features to the definition of the gekkonid type described by Wever \& Werner (1970). The 804 posterior extension of the pars superior and the shape of the anterior process and its projections 805 could be diagnostic characters for Gekkota, and the variation present within these features may 806 even be further diagnostic within the group as well. For this reason, we recommend more 807 detailed analysis in a systematic context.

808 The simplest type of the middle ear is that of the scincids, which was described in Scincidae, 809 Anguidae, and Xantusiidae (see Wever, 1978; Table 5-III). Interestingly however, the family 810 Xantusiidae actually shows two different middle ear types: the scincid type is seen in

811 Lepidophyma flavimaculatum and L. smithi, that do not possess both the internal process and the 812 extracolumellar muscle; and the iguanid type is observed in Xantusia henshawi, which does have 813 the internal process (Wever, 1978). The absence of the extracolumellar muscle was not evaluated 814 in the latter species, but the absence of the internal process was corroborated here in the genus 815 Mabuya (Scincidae).

816 The "divergent" or "degenerate" (as called by Wever [1978]) middle ears are those with a 817 morphology that does not match with any of the three previously mentioned types (Wever \& 
818 Werner, 1970; Wever, 1973, 1978). However, all genera described by Wever (1973) as divergent

819 forms, except those in the genus Anguis, exhibit an internal process, which is small and, in some 820 cases, extremely reduced (Wever, 1973). According to Wever (1978), divergent middle ears are 821 present in Chamaeleonidae, and Xenosauridae, as well as in some species of Agamidae and 822 Scincidae, and less frequently in some species of the families Anguidae, Pygopodidae, Teiidae, 823 and in several families of Iguania (Wever, 1978; Table 5-III). The genus Feylinia and the 824 families Dibamidae and Lanthanotidae also show this type of middle ear (McDowell, 1967;

825 Baird, 1970; Wever, 1978). The genera Anguis, Anniella, Callisaurus, Ceratophora, 826 Cophosaurus, Draco, Holbrookia, Phrynocephalus, Phrynosoma, and Xenosaurus show a 827 divergent pattern (Wever, 1973). All of them lack the tympanic membrane and exhibit an 828 extreme reduction in the extracolumella.

829

830 Ancestral state reconstructions. Ancestral state reconstructions of the available information 831 indicated that at least some extracolumella features can be a useful source of systematic 832 information within Squamata. The great uncertainty shown by the analyses for the ancestral state 833 of the length of the columella relative to the extracolumella central axis length (character 1, Fig. 834 7) suggests that there is no phylogenetic signal associated with this feature. The parsimony 835 analysis shows an ambiguous ancestral node between the longer and shorter states, while there 836 are no differences between the results of Bayesian models ARD and ER where the probability of 837 the ancestral condition is equal for all states (Table 5; Fig. S1-S2). The variation observed in this 838 ratio could be related to the auditory sensitivity associated with the inner ear, as well as 839 morphological or morphometrical features of the skull and the outer ear, or even ecological 840 conditions. 
841 To understand the evolutionary history of the extracolumella, the different morphological

842 variations and the particular shapes of its processes should be evaluated in more detail and within

843 less inclusive groups. However, simplifying the available information into only four states:

844 extracolumella simple, complex, elongated, and absent (character 2, Fig. 8A) provides at least a

845 broad idea of the overall variation and the general evolutionary history of the extracolumella in

846 lizards. While the presence of a simple extracolumella is the ancestral condition of Squamata, the

847 complex extracolumella appears to have arisen via convergence in Gekkota, Pleurodonta, and

848 Xantusiidae, and could be a diagnostic character (along with other features) for members of these

849 groups. The families Agamidae, Lacertidae, and Phrynosomatidae are polymorphic in that

850 different members of these clades exhibit a simple or complex extracolumella (Fig. 8A).

851 Although there are four extracolumellar processes exhibited in Xantusiidae (Wever, 1978),

852 Agamidae, and Lacertidae (this study), the anterior process in the first family and the anterior

853 and posterior processes in the latter two, are extremely small and thin structures, giving a similar

854 appearance to the simple extracolumella, emphasizing the necessity for detailed observation in

855 species that apparently lack any processes.

856 The elongated extracolumella is extremely different morphologically and is present only in

857 Amphisbaenidae and Trogonophidae. It is a cartilaginous structure that runs anteriorly along the

858 quadrate and is attached to the skin which functions as a sound-receptive surface (Wever \&

859 Gans, 1973; Wever, 1978). The origin of the amphisbaenian extracolumella has been a

860 controversial topic since Fürbringer $(1919,1922)$ proposed that it originated from the epihyal

861 portion of the hyoid apparatus, while Camp (1923) stated that these structures are not related.

862 Later, based on their personal observations, Wever \& Gans (1972, 1973) supported Fürbringer's

863 proposal, suggesting that the amphisbaenian extracolumella is not homologous with that of 
864 lizards, but instead is a modification of a dorsal portion of the hyoid (see Wever \& Gans, 1973).

865 However, according to Kearney (2003), this hypothesis has not been tested since there are no

866 studies about the development of amphisbaenians that have found any relation between the

867 extracolumella and the hyoid. Considering the statement of Kearney (2003), we consider the

868 extracolumella of Amphisbaenidae and Trogonophidae as a structure homologous with the lizard

869 extracolumella. Whenever it is present, the extracolumella always connects with the dermal layer

870 of the skin in members of the amphisbaenian clade. Aside from this however, members of this

871 group exhibit wide variation in extracolumellar morphology. This variation is present in the

872 family Rhineuridae that despite having a reduced extracolumella, also exhibits an unusual

873 morphology in that it has two branches of ligament fibers - one connected with the lower jaw

874 and the other with the upper jaw (Wever, 1978). Another kind of variation is present in

875 Diplometopon zarudnyi (Trogonophidae) whose extracolumella has a triangular blade shape

876 extending anteriorly over the skull's lateral surface with its posterior third cartilaginous and a

877 heavily calcified outer surface (Gans \& Wever, 1975). In these species, the sound-receiving

878 surface is not a tympanic membrane but a particular cephalic scale area. Sounds are transmitted

879 through the ground, and their vibrations are detected when the specimen has its head in contact

880 with the substrate (Wever \& Gans, 1972, 1973). These modifications are part of a suite of

881 advantageous features for a fossorial lifestyle in amphisbaenians (Baird, 1970; Wever \& Gans, $8821972,1973)$.

883 The genus Aprasia, and the families Bipedidae and Blanidae, do not have

884 extracolumellas indicating at least two independent losses of the extracolumella in Squamata.

885 The genus Aprasia does not have a tympanic membrane, a columellar apparatus, or a tympanic

886 cavity (Baird, 1970; Wever, 1978), although some species might have a small tympanic 
887 membrane and a very rudimentary columella. The morphology of the inner ear and some

888 anatomical modifications in the pterygoid and quadrate of Aprasia repens denote normal

889 auditory function, where the quadrate plays a role in sound transmission (Daza \& Bauer, 2015).

890 These observations suggest a limited ability to hear airborne sounds, but also potential capacity

891 to hear "underground sound" (Greer, 1989; Daza \& Bauer, 2015). In Aprasia repens

892 (Pygopodidae), the pterygoid and quadrate bones are the ones that show the morphological

893 modification to favor the auditory function in this burrower gecko. Low-frequency vibrations are

894 intercepted by the lower jaw, and its transmission into the middle ear might be through the

895 quadrate. The pterygoid is not in contact with the quadrate to prevent the entrance of the

896 vibrations into the palate (Daza \& Bauer, 2015). The ear modifications are one distinctive feature

897 of the extremely divergent morphological condition of the fossorial adaptation that this genus

898 shows (Baird, 1970). The loss of the extracolumella also occurred in the ancestor of the clade

899 (Bipedidae $+($ Blanidae + Cadeidae $)($ Amphisbaenidae + Trogonophidae $))$, but it appears again as

900 an expanded structure in Amphisbaenidae and Trogonophidae. In this clade, we could expect that

901 Cadeidae, a family with no current information, does not have an extracolumella (see below),

902 similar to Bipes (Bipedidae) and Blanus (Blanidae) that lack the external ear and only have a

903 columella that ends in a disk of fibrous tissue beneath the skin, resulting in a very aberrant sound

904 receiving system, but with a high level of sensitivity stimulated by aerial sounds (Wever \& Gans, 905 1972, 1973).

906 In the ancestral reconstruction of character 2 (Extracolumella), the results of the ARD

907 and ER Bayesian approaches show some differences in the probability values for the ancestral

908 state estimates for the clades Gekkota, Pleurodonta, and Xantusiidae. However, both analyses

909 show the highest support for the complex extracolumella at the ancestral node of the three clades, 
910 consistent with the parsimony results (Table 5; Fig. S3). A second difference between the two

911 Bayesian analyses was in the probability values of the nodes within the amphisbaenian clade. In

912 this case, both analyses still estimated the highest probability for the elongated extracolumella at

913 the ancestral node of (Amphisbaenidae + Trogonophidae), agreeing with the parsimony results.

914 Contrary to this, the ARD model shows the highest probability values for the elongated

915 extracolumella in the ancestral nodes of (Bipedidae + (Blanidae + Cadeidae) (Amphisbaenidae +

916 Trogonophidae)), ((Blanidae + Cadeidae) (Amphisbaenidae + Trogonophidae)), and (Blanidae +

917 Cadeidae), suggesting the presence of an elongated extracolumella in Cadeidae. In contrast, the

918 ER model, concordant with the parsimony results, shows the highest support for the absent

919 extracolumella at the ancestral nodes for these clades, proposing the absence of an

920 extracolumella in Cadeidae (Table 5; Fig. S1, S3).

921 Serpentes have a long and narrow columella with a cartilaginous end that connects with

922 the quadrate through an articulatory process, and in some groups, intermediate cartilages may

923 also be observed between both structures (Wever, 1978). The identity of the cartilaginous

924 columella end, as well as the intermediate cartilages, is uncertain. According to Rieppel \& Zaher

925 (2000), the columella's cartilaginous end may be homologous to the internal process rather than

926 the main body of the extracolumella. Furthermore, according to Kamal \& Hammouda (1965), the

927 intermediate cartilages are intercalary structures between the articular process and the

928 cartilaginous end of the columella, while McDowell (1967) considered these as the internal

929 process of the columella and a piece of the extracolumella. Since there is no consensus about the

930 nature of the extracolumella in Serpentes and that this subject is beyond the focus of this study,

931 we cannot make any assumptions about this. Nevertheless, it is fundamental to define the 
932 cartilages' identity related to Serpentes' columella end and study its variation, to establish a more 933 accurate hypothesis about the evolutionary history of the extracolumella in lizards.

934 The ancestral reconstruction of the internal process (character 3; Fig. 8B) shows differences

935 between analyses that do not permit establishing the ancestral state (presence or absence) for this 936 character for Squamata, along with some of the other more ancestral nodes within this group 937 (Fig. 8B). The absence of this process is likely a result of convergence occurring between the 938 groups of Gekkota, Gymnophthalmidae, and Scincidae (Fig. 8B); while the presence of this 939 process is the more common state within Squamata. Based on the available information, the 940 families Anguidae and Xantusiidae are the only ones which are polymorphic for this character 941 state. The result of the parsimony analysis indicated the absence of the internal process as the 942 ancestral condition of Squamata, but the Bayesian analyses differs of it. The ARD model result 943 shows the presence of the internal process as the ancestral condition, while the ER model show 944 similar probabilities between absence and presence of this process (Table 5; Fig. S1, S4). For the 945 Gekkota, Gymnophthalmidae, and Scincidae clades, the results of the different analyses of the 946 ancestral reconstruction agree, showing as the ancestral condition with the absence of the internal 947 process in these groups (Table 5; Fig. S1, S4).

948 The fossil record shows that the middle ear of the ancestral lepidosaurs have a tympanic 949 membrane and that the lack of this structure in Sphenodon is the result of a secondary loss, 950 possibly related to feeding specializations (Evans, 2016). There are few details about the 951 morphology of the middle ear of stem squamates. According to Evans (2016), the squamate 952 fossil record from the Early Cretaceous with well-preserved skulls only shows evidence of the 953 ear anatomy by the presence of a quadrate with a lateral conch and tympanic crest. Nevertheless, 954 one specimen of the Early Cretaceous lizard, Liushusaurus acanthocaudata (Evans and Wang 
955 2010), shows traces of the cartilaginous extracolumella that lie adjacent to the tympanic region 956 (Evans, 2016). The fossil record shows the derived condition, indicating that squamates evolved 957 the tympanic ear according to their different specialized lifestyles (Evans, 2016).

958 The columella and extracolumella morphologies have not been associated functionally 959 with lizards' vocalizing capabilities. However, given the high morphological complexity of the 960 extracolumella described in the geckos' clade, it could probably be correlated with the 961 vocalizations that they produce which are complex and exhibit variation in amplitude and

962 frequency (Russell and Bauer, 2020). On the other hand, Wever (1978) considered a correlation 963 between the vocalization and the meatal closure muscle of the outer ear in these lizards.

964 According to Wever (1978), the function of the meatal closure muscle is to protect the ear; 965 although it is not clear if this protection is only against mechanical damage or also against 966 particularly loud sounds. This muscle could be related to the fact that these lizards produce 967 vocalizations, and hence the muscle plays a role in protecting the individual's ears against its 968 own vocal sounds, which can be extremely loud in some species. However, in some individuals 969 of the family Sphaerodactylidae and the gekkonid genus Phelsuma, which are considered to be 970 mute species, or with tenuous vocalization, don't have this muscle; other species (e.g., Gehyra 971 variegata, Oedura monilis (= Oedura ocellata), and Strophurus elderi (= Diplodactylus 972 elderi)) that also do not produce vocalizations, do have the meatal closure muscle in their outer 973 ears (Wever, 1978). Thus, while the production of loud vocalization might be related to the

974 presence of the meatal closure muscle, it is clear that other conditions may also produce the 975 development of this muscle (Wever, 1978). Alternatively, it can be assumed that the presence of 976 the meatal closure muscle and vocalization are the ancestral condition for gekkotans, and in 977 some groups the muscles have been lost along with vocalization, whilst in others the muscles 
978 haven't been lost yet. We cannot also rule out that this muscle has an unknown alternative

979 function. The combined analysis of morphological and functional information is necessary to

980 establish the possible relation between the outer and middle ear with geckos' vocalizations.

981 Despite the general morphology of the lizard middle ear being quite well known, and

982 there being no particularly notable variation in the lizard columella, the morphological variation

983 of the extracolumella structure is evidently more significant than previously described. We have

984 presented evidence of that extensive variation here and demonstrated that some features of the

985 extracolumella could potentially provide a source of phylogenetic information for some groups.

986 However, in some clades, other ear modifications may be more closely related to adaptations for

987 navigating and functioning within particular habits. It is necessary to perform a more detailed

988 and comprehensive study around each of the specific morphologies of the extracolumella, here

989 defined as: simple, complex, and elongated, to understand better the variation present within

990 each particular clade. This kind of detailed information will possibly let us know about more

991 morphological features that may be useful to the systematic and understanding of the functioning

992 of the middle ear in certain groups of lizards.

993

994 Conclusions

995 The middle ear in lizards shows considerable morphological variation. Although the columella

996 morphology is more conservative, the structures that conform to the extracolumella show a large

997 amount of variation than previously described, mainly in the pars superior and anterior process.

998 Significant morphological variation of the internal process is expected given the vast diversity of

999 the species that present this process and the evidence of a possible functional variation. These

1000 extracolumellar structures should be studied in more detail to complete as much as possible the

1001 gap of the information, especially within lizards' groups that have a complex extracolumella, 
1002 which may present considerable morphological variation. Even though this study describes the

1003 variation of these structures only in some lizard species, this information gives us an idea about

1004 the amount of morphological variation that we could find across the Squamata. The analysis of

1005 this morphology within a comparative and evolutive framework shows us that these structures

1006 are a substantial source of systematic and phylogenetic information, which could be useful even

1007 to functional studies. The results of the ancestral reconstruction show high levels of homoplasy

1008 in the variation of the columella-extracolumella length ratio, while pointing out as the ancestral

1009 condition of Gekkota, Pleurodonta, and Xantusiidae the presence of a complex extracolumella;

1010 and in Gekkota, Gymnophthalmidae, and Scincidae, the absence of the internal processes.

1011 Furthermore, we can consider as diagnostic characteristics of Gekkota the presence of a posterior

1012 extension in the pars superior and an anterior process with some small and sharp projections. A

1013 more accurate description of each process of the extracolumella and its variation within less

1014 inclusive groups should be evaluated in more detail to establish the taxonomic and systematic

1015 value of these features. There is not enough information about the condition of the middle ear

1016 structures studied here to cover the complete clade of squamates, for that reason the only

1017 ancestral condition defined to this group was a presence of a extracolumella with less than four

1018 processes. The morphological variation of both the columella and extracolumella may have a

1019 distinctive role associated with their efficiency in transmitting the sound, and with the

1020 vocalizations produced by some clades. Also, the variation of the extracolumellar structures

1021 probably is correlated with different morphological patterns of the outer ear, which at the same

1022 time are related to the specific habitats of each squamates group. These correlations should be

1023 established by studying the morphological and functional association between the middle and

1024 outer ear with the vocalizations within an ecological context. 
1025

1026 Acknowledgements

1027 We would like to thank Martha Lucia Calderón (Instituto de Ciencias Naturales ICN,

1028 Universidad Nacional de Colombia), Juan Manuel Daza (Collection of Reptiles of the Museo de

1029 Herpetología MHUA, Universidad de Antioquia), and Hussam Zaher and Aline Staskowian

1030 Benetti (Museu de Zoologia MZUSP, Universidade de São Paulo), for providing access to

1031 specimens under their care. We also like to express our thanks to Rebecca Laver (Australian

1032 National University) and Stephanie Baker (Sam Houston State University) for their valuable

1033 comments to the previous version of this manuscript, and to Julia Schultz and Michael Caldwell

1034 for their insightful review of the work. PMSN is grateful to Dione Seripierri and the team of the

1035 Library of the MZUSP for your invaluable help in obtaining some of the key bibliographical

1036 references.

1037

1038 References

1039 Baird IL. 1960. A survey of the periotic labyrinth in some representative recent reptiles.

$1040 \quad$ University of Kansas Science Bulletin 41:891-981.

1041 Baird IL. 1967. Some histological and cytological features of the basilar papilla in lizards Anolis carolinensis. [Abstract] Anatomical Record 157: 208-209.

1043 Baird IL. 1970. The anatomy of the reptilian ear. In: Gans C and Parsons TS, eds. Biology of 1044 Reptilia, Vol 2. Morphology B. London: Academic Press, 193-375.

1045 Baird IL, Marovitz WF. 1971. Some findings of scanning and transmission electron microscopy 1046 of the basilar papilla of the lizard Iguana iguana. [Abstract] Anatomical Record 169: 270.

1047 Bauer AM. 1990. Phylogenetic systematics and biogeography of the Carphodactylini (Reptilia, 1048 Gekkonidae). Bonner zoologische Monographien 30: 1-217. 
1049 Bauer AM, Beach-Mehrotra M, Bermudez Y, Clark GE, Daza JD, Glynne E, Hagyari D, 1050 Harnden JM, Holovacs N, Kanasiro A, Lofthus AJ, Pierce ZW, Aaliyah R, Syed S, 1051 Vallejo-Pareja MC, Walker BA, Willett J. 2018. The Tiny Skull of the Peruvian Gecko 1052 Pseudogonatodes barbouri (Gekkota: Sphaerodactylidae) Obtained via a Divide-And-

1053 1054

1055 1056 1057

1058

1059 1060 1061

1062 1063

1064

1065

1066 1067

1068

1069

1070

1071

1072

1073

1074

1075

1076 1077

Conquer Approach to Morphological Data Acquisition. South American Journal of Herpetology 13(2): 102-116 DOI.org/10.2994/SAJH-D-17-00113.1.

Bauer AM, Good DA, Branch WR. 1997. The taxonomy of the southern African leaf-toed geckos (Squamata: Gekkonidae), with a review of Old World "Phyllodactylus" and the description of five new genera. Proceedings of the California Academy of Sciences 49(4): 447-497.

Berman DS, Regal PJ. 1967. The Loss of the Ophidian Middle Ear. Evolution 21(3):641-643. Camp CL. 1923. Classification of the lizards. Bulletin of the American Museum of Natural History 48: 289-481.

Clack JA. 1997. The evolution of tetrapod ears and the fossil record. Brain, Behavior and Evolution 50: 198-212 DOI: 10.1159/000113334.

Clack JA. 2002. Patterns and processes in the early evolution of the tetrapod ear. Journal of Neurobiology 53: 251-264 DOI:10.1002/neu.10129.

Daza JD, Aurich J, Bauer AM. 2012. Anatomy of an enigma: an osteological investigation of the Namibian festive gecko (Narudasia festiva: Gekkonidae: Gekkota). Acta Zoologica 93(4): 465-486 DOI: 10.1111/j.1463-6395.2011.00521.x.

Daza JD, Bauer AM. 2015. Cranial anatomy of the pygopodid lizard Aprasia repens, a gekkotan masquerading as a scolecophidian. In: Bininda-Emonds OR P, Powell GL, Jamniczky HA, Bauer AM and Theodor JM, eds. All Animals are Interesting: A Festschrift in Honour of Anthony P. Russell. Oldenburg, Germany: BIS Verlag, 303-350.

Daza JD, Gamble T, Abdala V, Bauer AM. 2017. Cool geckos: does plesiomorphy explain morphological similarities between geckos from the southern cone? Journal of Herpetology 51(3): 330-342 DOI: 10.1670/16-162.

Earle AM. 1961a. The middle ear of Holbrookia maculata maculata, the northern earless lizard. Copeia 1: 68-74.

Peerj reviewing PDF | (2020:12:56089:3:0:NEW 5 Jun 2021) 
1078 Earle AM. 1961b. An additional note on the ear of Holbrookia maculata. Copeia 3: 355.

1079 Earle AM. 1961c. The Middle Ear of Holbrookia and Callisaurus. Copeia 4: 405-410.

1080 Estes R, de Queiroz K, Gauthier J. 1988. Phylogenetic relationships within Squamata. In: Estes

1081 R and Pregill G, eds. Phylogenetic Relationships of the Lizard Families, Essays

1082 Commemorating Charles L. Camp. Stanford University Press, 119-281.

1083 Evans SE. 2008. The skull of lizards and tuatara. In: Gans C, Gaunt AS and Adler K, eds.

1084 Biology of the Reptilia, Vol 20, Morphology H: The skull of Lepidosauria. Ithaca: Society 1085 for the Study of Amphibians and Reptiles, 1-347.

1086 Evans SE. 2016. The Lepidosaurian Ear: Variations on a Theme. In: Clack J, Fay R, Popper A, 1087 eds. Evolution of the Vertebrate Ear. Springer Handbook of Auditory Research, vol 59. $1088 \quad$ Springer, 245-284

1089 Fürbringer M. 1919. Über das Zungenbein der Reptilien. Bijdragen Tot de Dierkunde k, zoolog. 1090 geneetschap. Amsterdam, Feest Nummer für Kerbert, 195-212.

1091

Fürbringer, M. 1922. Das zungenbein der wirbeltiere insbesondere der reptilien und vögel.

1093

1094

1095

1096

1097

1098

1099

1100

1101

1102

1103

1104 1105

nachgelassene untersuchungen über systematische phylogenie mit besonderer berücksichtigung der wurzel der säugetiere. Berlin: Abhandlingen der Heidelberger Akademie der Wissenschaften.

Gans C. 1978. The characteristics and affinities of the Amphisbaenia. Transactions of the Zoological Society of London 34(4): 347-416 DOI: 10.1111/j.1096-3642.1978.tb00376.x.

Gans C, Wever EG. 1972. The Ear and Hearing in Amphisbaenia (Reptilia). Journal of Experimental Zoology 179(1): 17-34.

Gans C, Wever EG. 1975. The Amphisbaenian Ear: Blanus cinereus and Diplometopon zarudnyi. Proceedings of the National Academy of Sciences of the United States of America 72(4): 1487-1490.

Gans C, Wever EG. 1976. Ear and Hearing in Sphenodon punctatus. Proceedings of the National Academy of Sciences of the United States of America 73(11): 4244-4246.

Gauthier J, Estes R, de Queiroz K. 1988. A phylogenetic analysis of Lepidosauromorpha. In: Estes R and Pregill G, eds. Phylogenetic relationships of the lizard families - Essays

Peer) reviewing PDF | (2020:12:56089:3:0:NEW 5 Jun 2021) 
1106

1107

1108

1109

1110

1111

1112

1113

1114

1115

1116

1117

1118

1119

1120

1121

1122

1123

1124

1125

1126

1127

1128

1129

1130

1131

1132

commemorating Charles L. Camp. California: Stanford, California, University Press, 1598.

Goodrich ES. 1958. Studies on the structure and development of vertebrates. Reprint of the original 1930 edition. New York: Dover Publications, Inc.

Gray AA. 1913. Notes on the comparative anatomy of the middle ear. Journal of Anatomy and Physiology 47:391-413.

Greer AE. 1976. On the Occurrence of a Stapedial Foramen in Living Non-Gekkonid Lepidosaurs. Copeia 3: 591-592.

Greer AE. 1989. The biology and evolution of Australian lizards. Chipping Norton, New South Wales: Surrey Beatty \& Sons Pty Limited.

Han D, Young BA. 2016. Anatomical Basis of Dynamic Modulation of Tympanic Tension in the Water Monitor Lizard, Varanus salvator. Anatomical Record 299: 1270-1280.

Hedges SB, Conn CE. 2012. A new skink fauna from Caribbean islands (Squamata, Mabuyidae, Mabuyinae). Zootaxa 3288: 1-244.

Holovacs NT, Daza JD, Guerra C, Stanley EL, Montero R. 2020. You can't run, but you can hide: the skeleton of the sand-swimmer lizard Calyptommatus leiolepis (Squamata: Gymnophthalmidae), Anatomical Record 303: 1305-1326.

Iordansky NH. 1968. Muscles of the external ear in some lizards. [in Russian]. Zoologicheskii zhurnal 47: 1730-1732.

Jollie MT. The head skeleton of the lizard. Acta Zoologica 41:1-64.

Kamal AM. 1961. The common characters of the gekkonid chondrocranium. Anatomischer Anzeiger 109: 109-113.

Kamal AM, Hammouda HG. 1965. The columella auris of the snake, Psammophis sibilans. Anatomischer Anzeiger 116, 124-123

Kearney M. 2003. Systematics of the Amphisbaenia (Lepidosauria: Squamata) based on morphological evidence from recent and fossil forms. Herpetological Monographs 17: 174.

Peer] reviewing PDF | (2020:12:56089:3:0:NEW 5 Jun 2021) 
1133 Kearney M, Maisano JA, Rowe T. 2005. Cranial Anatomy of the Extinct Amphisbaenian

1134

1135

1136

1137

1138

1139

1140

1141

1142

1143

1144

1145

1146

1147

1148

1149

1150

1151

1152

1153

1154

1155

1156

1157

1158

1159
Rhineura hatcherii (Squamata, Amphisbaenia) Based on High-Resolution X-ray Computed Tomography. Journal of Morphology 264: 1-33.

Kluge AG. 1987. Cladistic relationships in the Gekkonoidea (Squamata, Sauria). Miscellaneous Publications, Museum of Zoology, University of Michigan 173.

Kluge AG, Eckhardt MJ. 1969. Hemidactylus garnotii Duméril and Bibron, a Triploid AllFemale Species of Gekkonid Lizard. Copeia 4: 651-664.

Kluge AG, Nussbaum RA. 1995. A review of African-Madagascan gekkonid lizard phylogeny and biogeography (Squamata). Miscellaneous Publications, Museum of Zoology, University of Michigan 183.

Lombard RE, Bolt JR. 1979. Evolution of the tetrapod ear: an analysis and reinterpretation. Biological Journal of the Linnean Society 11(1): 19-76 DOI: 10.1111/j.10958312.1979.tb00027.x.

Maddison WP, Maddison DR. 2018. Mesquite: a modular system for evolutionary analysis. Version 3.51. Available at http://www.mesquiteproject.org

Manley GA. 1972a. Frequency response of the ear of the tokay gecko. Journal of Experimental Zoology 181(2): 159-168 DOI:10.1002/jez.1401810203.

Manley GA. 1972b. The middle ear of the tokay gecko. Journal of Comparative Physiology 81(3): 239-250 DOI: 10.1007/BF00693629.

Manley GA. 2000. Cochlear mechanisms from a phylogenetic viewpoint. Proceedings of the National Academy of Sciences of the United States of America 97: 11736-11743 DOI: 10.1073/pnas.97.22.11736.

Manley GA. 2010. An evolutionary perspective on middle ears. Hearing Research 263: 3-8.

Manley GA. 2011. Lizard auditory papillae: An evolutionary kaleidoscope. Hearing research 273(1-2): 59-64 DOI: 10.1016/j.heares.2010.02.015.

Mason MJ, Farr MRB. 2013. Flexibility within the middle ears of vertebrates. Journal of Laryngology \& Otology 127 (01): 2-14.

Peerj reviewing PDF | (2020:12:56089:3:0:NEW 5 Jun 2021) 
1160 McDowell SB. 1967. The Extracolumella and Tympanic Cavity of the "Earless" Monitor Lizard, 1161 Lanthanotus borneensis. Copeia 1: 154-159.

1162 Miller MR. 1974. Scanning microscocopy of the lizard papilla basilaris. Brain, Behavior and 1163 Evolution 10: 95-112 DOI:10.1159/000124305.

1164 O’Leary MA, Kaufman SG. 2012. MorphoBank 3.0: Web application for morphological 1165 phylogenetics and taxonomy. Available at http://www.morphobank.org.

1166 Olson EC. 1966. The middle ear-morphological types in amphibians and reptiles. American 1167 Zoologist 6(3): 399-419 DOI: 10.1093/icb/6.3.399.

1168 Peterson EA. 1966. Hearing in the Lizard: Some Comments on the Auditory Capacities of a $1169 \quad$ Nonmammalian Ear. Herpetologica 22(3): 161-171.

1170 Pethiyagoda R, Manamendra-Arachchi K. 1998. A revision of the endemic Sri Lankan agamid 1171 lizard genus Ceratophora Gray, 1835, with description of two new species. Journal of South Asian natural history 3(1): 1-50.

1173 Posner RB, Chiasson RB. 1966. The middle ear of Coleonyx variegatus. Copeia 3: 520-524.

1174 R Core Team (2020). R: A language and environment for statistical computing. R Foundation for 1175 Statistical Computing, Vienna, Austria. Available at URL https://www.R-project.org/.

1176 Revell LJ. 2012. Phytools: An R package for phylogenetic comparative biology (and other 1177 things). Methods in Ecology and Evolution 3: 217-223 DOI:10.1111/j.2041-

1179 Rieppel O. 1980. The Phylogeny of Anguinomorph Lizards. Basel, Boston, Stuttgart: Birkhäuser $1180 \quad$ Verlag.

1181 Rieppel O. 1984. The cranial morphology of the fossorial lizard genus Dibamus with a 1182 consideration of its phylogenetic relationships. Journal of Zoology 204(3): 289-327

1183 DOI: 10.1111/j.1469-7998.1984.tb02376.x.

1184 Rieppel O, Zaher H. 2000. The braincases of mosasaurs and Varanus, and the relationships of 1185 snakes. Zoological Journal of the Linnean Society, 129, 489-514.

1186 Russell AP. Bauer AM. 2020. Vocalization by extant nonavian reptiles: A synthetic overview of 1187 phonation and the vocal apparatus. Anatomical Record doi: 10.1002/ar.24553 
1188 Saunders JC, Duncan RK, Doan DE, Werner YL. 2000. The middle ear of reptiles and birds. In: 1189 Dooling RJ, Fay RR and Popper, AN, eds. Comparative Hearing: Birds and Reptiles. New $1190 \quad$ York: Springer Verlag, 13-69.

1191 Schmidt RS. 1964. Phylogenetic significance of the lizard cochlea. Copeia 3: 542-549.

1192 Shute CCD, Bellairs A d'A, 1953. The cochlear apparatus of Geckonidae and Pygopodidae and 1193 its bearing on the affinities of these groups of lizards. Proceedings of the Zoological Society of London 123(3): 695-710 DOI: 10.1111/j.1096-3642.1953.tb00194.x.

Suga N, Campbell HW. 1967. Frequency sensitivity of single auditory neurons in the gecko, Coleonyx variegatus. Science 157: 88-90.

1197 Toerien MJ, 1963. The Sound-Conducting Systems of Lizards Without Tympanic Membranes. Evolution 17(4): 540-547.

1199

Underwood G. 1957. On lizards of the family Pygopodidae. A contribution to the morphology 1200 and phylogeny of the Squamata. Journal of Morphology 100: 207-268.

1201

1202 1203

1204 1205 1206

1207 1208

1209 1210

1211 1212 1213 1214

Versluys J. 1898. Die mittlere and äussere Ohrsphäre der Lacertilia and Rhynchocephalia, Zoologische Jahrbücher, Abteilung für Anatomie und Ontogenie der Tiere 12: 161-406.

Villa A, Daza JD, Bauer AM, Delfino M. 2018. Comparative cranial osteology of European gekkotans (Reptilia, Squamata). Zoological Journal of the Linnean Society 184 (3): 857895 DOI: 10.1093/zoolinnean/zlx104.

Werner YL, 1976. Optimal temperatures for inner-ear performance in gekkonoid lizards. Journal of Experimental Zoology 195(3): 319-351 DOI: 10.1002/jez.1401950302.

Werner YL, Igić PG. 2002. The middle ear of gekkonoid lizards: interspecific variation of structure in relation to body size and to auditory sensitivity. Hearing Research 167: 33-45.

Werner YL, Montgomery LG, Seifan M, Saunders JC. 2008. Effects of age and size in the ears of gekkotan lizards: auditory sensitivity, its determinants, and new insights into tetrapod middle-ear function. Pflügers Archiv - European Journal of Physiology 456(5): 951-967 DOI: $10.1007 / \mathrm{s} 00424-008-0462-0$. 
1215 Werner YL, Safford SD, Seifan M, Saunders JC. 2005. Effects of Age and Size in the Ears of

1216

1217

1218

1219

1220

1221

1222

1223

1224

1225

1226

1227

1228

1229

1230

1231

1232

1233

1234

1235

1236

1237

1238

1239

1240

1241

1242

Gekkonomorph Lizards: Middle-Ear Morphology with Evolutionary Implications. Anatomical Record Part A 283(1): 212-223 DOI: 10.1002/ar.a.20142.

Werner YL, Wever EG. 1972. The function of the middle ear in lizards: Gekko gecko and Eublepharis macularius (Gekkonoidea). Journal of Experimental Zoology 179(1): 1-16 DOI: $10.1002 /$ jez.1401790102.

Wever EG. 1967. The tectorial Membrane of the Lizard Ear: Types of structure. Journal of Morphology 122: 307-320.

Wever EG. 1968. The Ear of the Chameleon: Chamaeleo senegalensis and Chamaeleo quilensis. Journal of Experimental Zoology 168(4): 423-436. DOI:10.1002/jez.1401680403.

Wever EG. 1970. The lizad ear: Scincidae. Journal of Morphology 132: 277-292.

Wever EG. 1971. The ear of Basiliscus basiliscus (Sauria: Iguanidae) its structure and function. Copeia 1: 139-144.

Wever EG. 1973. The function of the middle ear in lizards: divergent types. Journal of Experimental Zoology 184(1): 97-125 DOI:10.1002/jez.1401840108.

Wever EG. 1974. The ear of Lialis burtonis (Sauria: Pygopodidae), its Structure and Function. Copeia 2: 297-305.

Wever EG. 1978. The Reptile Ear. Its Structure and Function. Princeton: Princeton University Press.

Wever EG, Gans C. 1972. The ear and hearing in Bipes biporus (Amphisbaenia: Reptilia). Proceedings of the National Academy of Sciences of the United States of America 69(9): 2714-2716.

Wever EG, Gans C. 1973. The ear in Amphisbaenia (Reptilia); further anatomical observations. Journal of Zoology 171(2): 189-206 DOI:10.1111/j.1469-7998.1973.tb02215.x.

Wever EG, Peterson EA. 1963. Auditory sensitivity in three iguanid lizards. Journal of Auditory Research 3: 205-212.

Wever EG, Vernon JA, Crowley DE, Peterson EA. 1965. Electrical output of lizard ear: relation to hair cell population. Science 150: 1172-1174.

Peer) reviewing PDF | (2020:12:56089:3:0:NEW 5 Jun 2021) 
1243 Wever EG, Vernon JA, Peterson EA, Crowley DE. 1963. Auditory responses in the Tokay gecko. Proceedings of the National Academy of Sciences of the United States of America 50(5): 806-811 DOI: 10.1073/pnas.50.5.806.

1246 Wever EG, Werner YL. 1970. The function of the middle ear in lizards: Crotaphytus collaris. Journal of Experimental Zoology 175(3): 327-341 DOI: 10.1002/jez.1401750307.

1248 Wibowo E, Brockhausen J, Köppl C. 2009. Efferent Innervation to the Auditory Basilar Papilla of Scincid Lizards. Journal of Comparative Neurology 516: 74-85.

1250 Zheng Y, Wiens JJ. 2016. Combining phylogenomic and supermatrix approaches, and a time1251 calibrated phylogeny for squamate reptiles (lizards and snakes) based on 52 genes and 4162 species. Molecular Phylogenetics and Evolution 94 (Pt B): 537-547 DOI: 10.1016/j.ympev.2015.10.009. 
Figure 1

Schematic representation of the middle ear of lizards. Illustrative sketch of the structures that conform the middle ear of lizards.

(A) Middle ear (from the posterior view of the skull); (B) extracolumella and tympanic membrane (from the lateral view of the skull). Modified from Mason and Farr (2013).

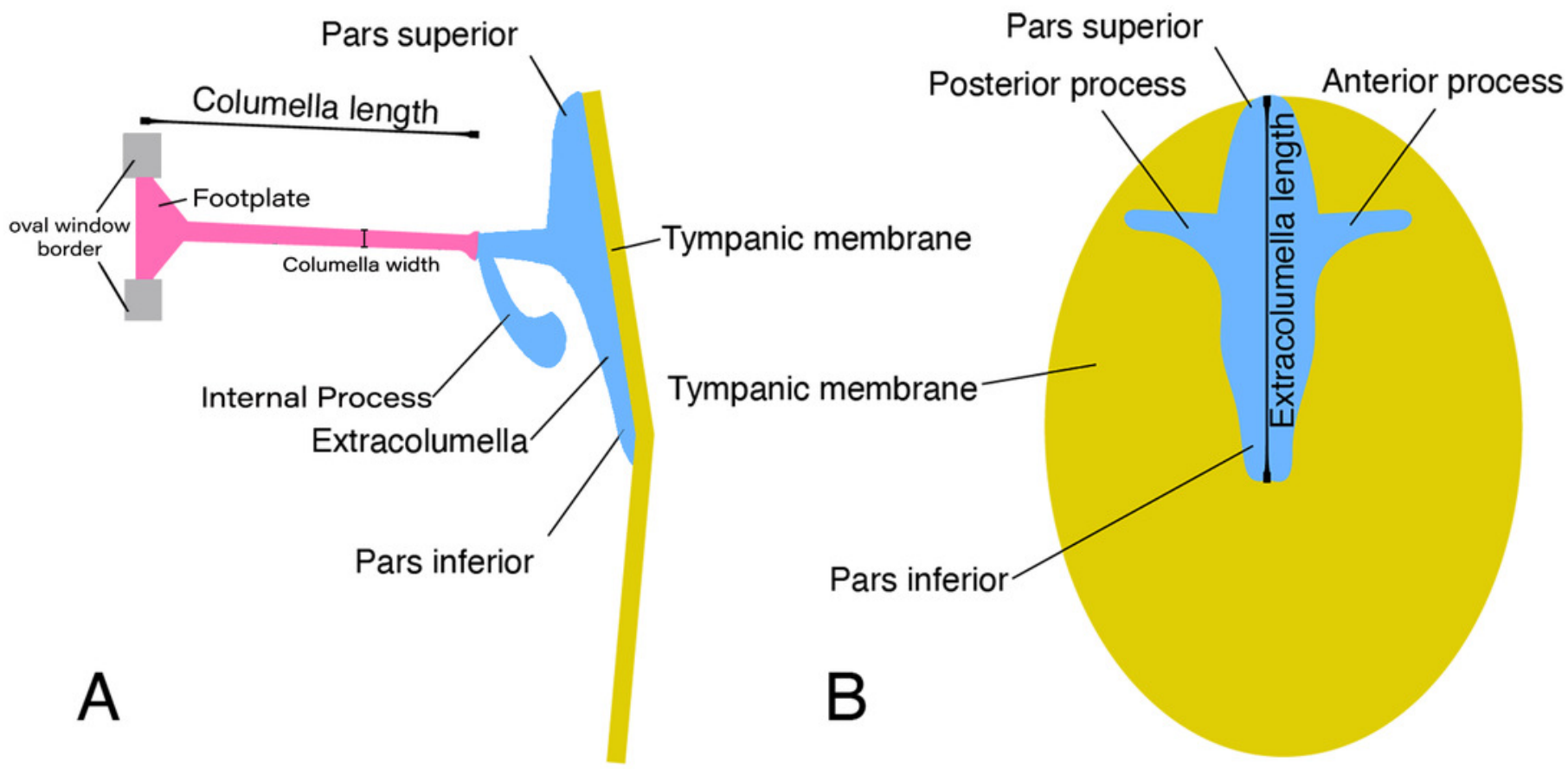




\section{Figure 2}

Middle ear. The middle ear is shown from the posterior view of the skull. The columella and the extracolumella (with its corresponding extracolumellar processes), have been sketched.

(A) Gonatodes concinnatus MUJ 733; (B) Hoplocercus sp. MZUSP 92161; (C) Tetrioscincus bifasciatus ICN 5588. Scale bars: $1 \mathrm{~mm}$.
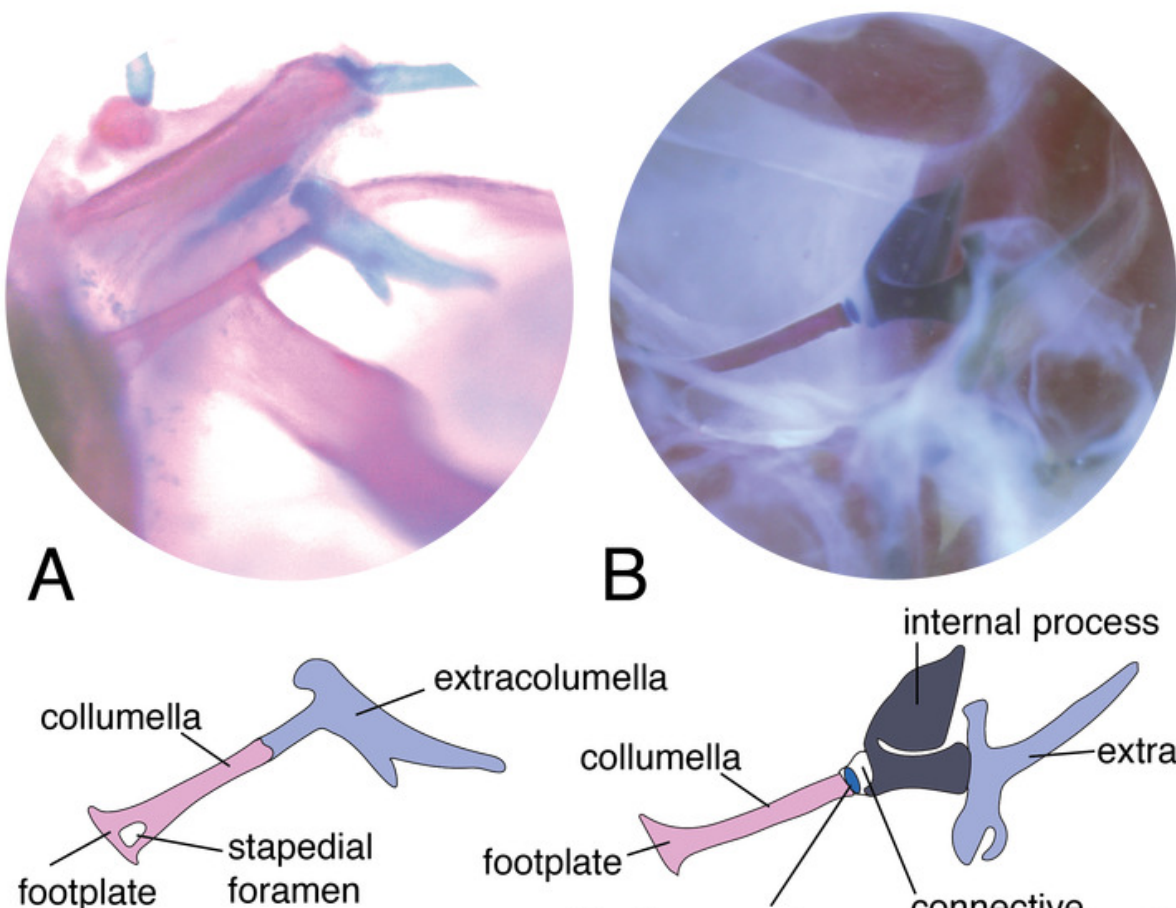

extracolumella

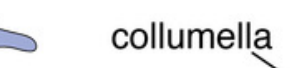
footplate cartilaginous end of the columella connective tissue

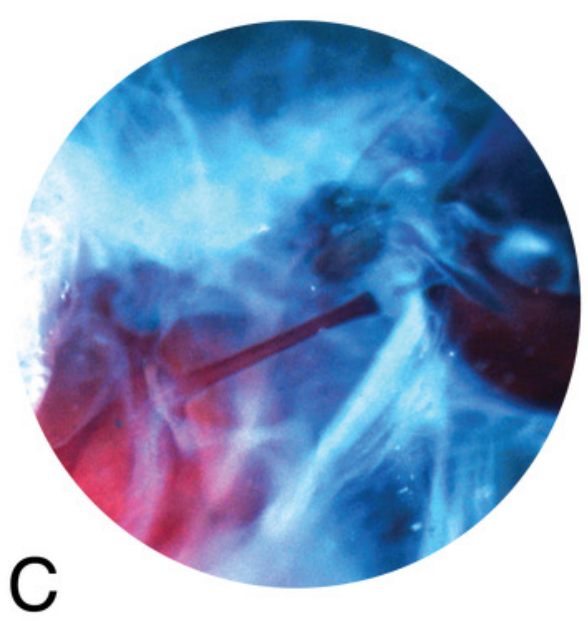

extracolumella

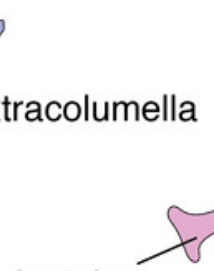

footplate

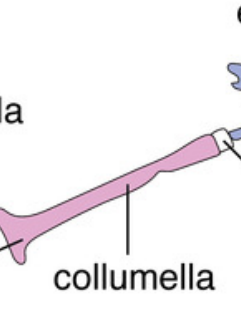

connective tissue 


\section{Figure 3}

Middle ear. The middle ear is shown from the posterior view of the skull. The columella and the extracolumella (with its corresponding extracolumellar processes), have been sketched.

(A) Stenocercus trachycephalus MUJ 635 (posterior view); (B) Lialis jicari MZUSP 67148 (posterior view); (C) Anolis maculiventris MHAU 10468 (posterior view). Scale bars: 2 mm.
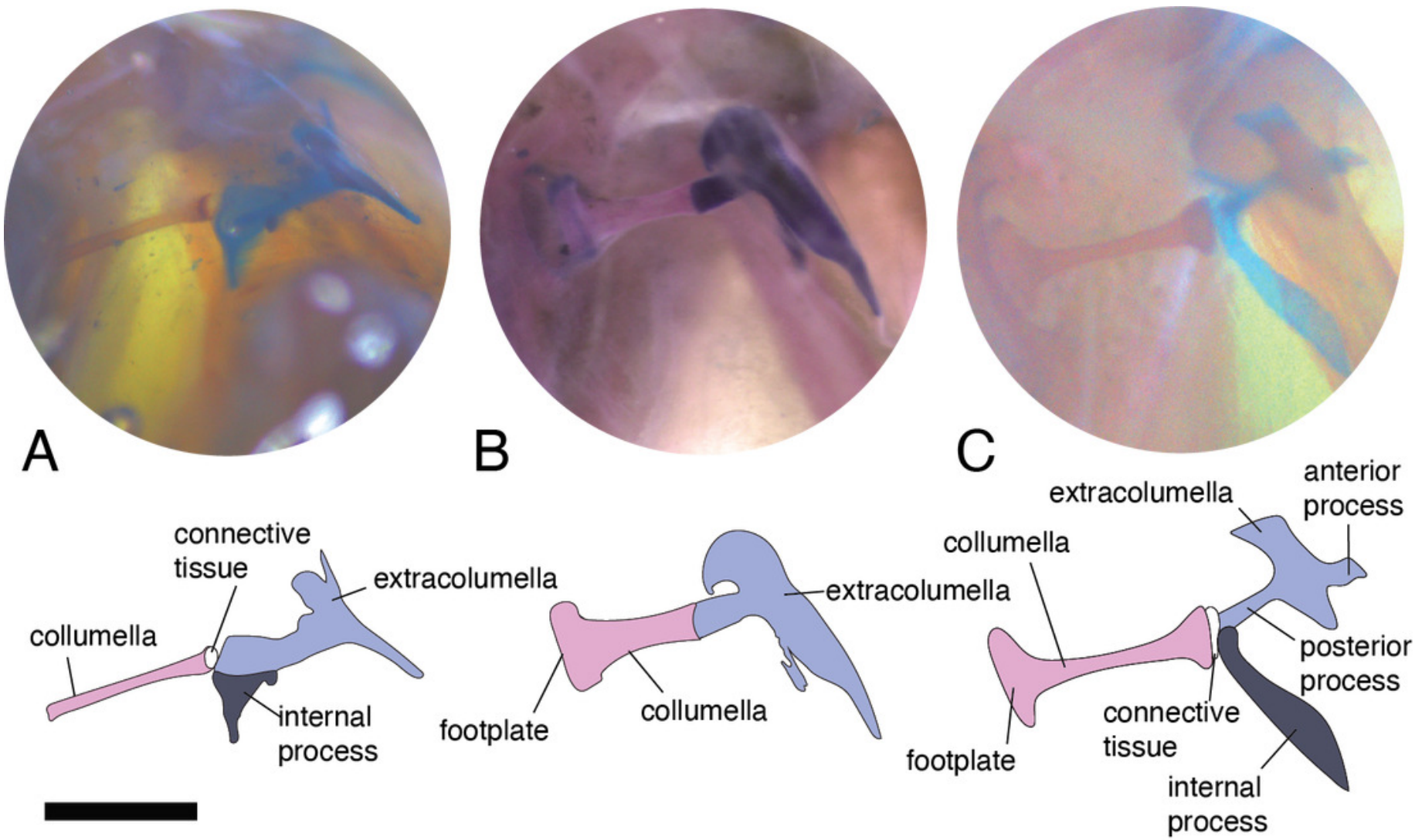


\section{Figure 4}

Extracolumella. The extracolumella is shown from the lateral view of the skull. The columella and the extracolumella (with its corresponding extracolumellar processes), have been sketched.

(A) Phelsuma madagascariensis MZUSP 36938; (B) Thecadactylus rapicauda MZUSP 97833;

(C) Lialis jicari MZUSP 67148. Scale bars: $1 \mathrm{~mm}$.

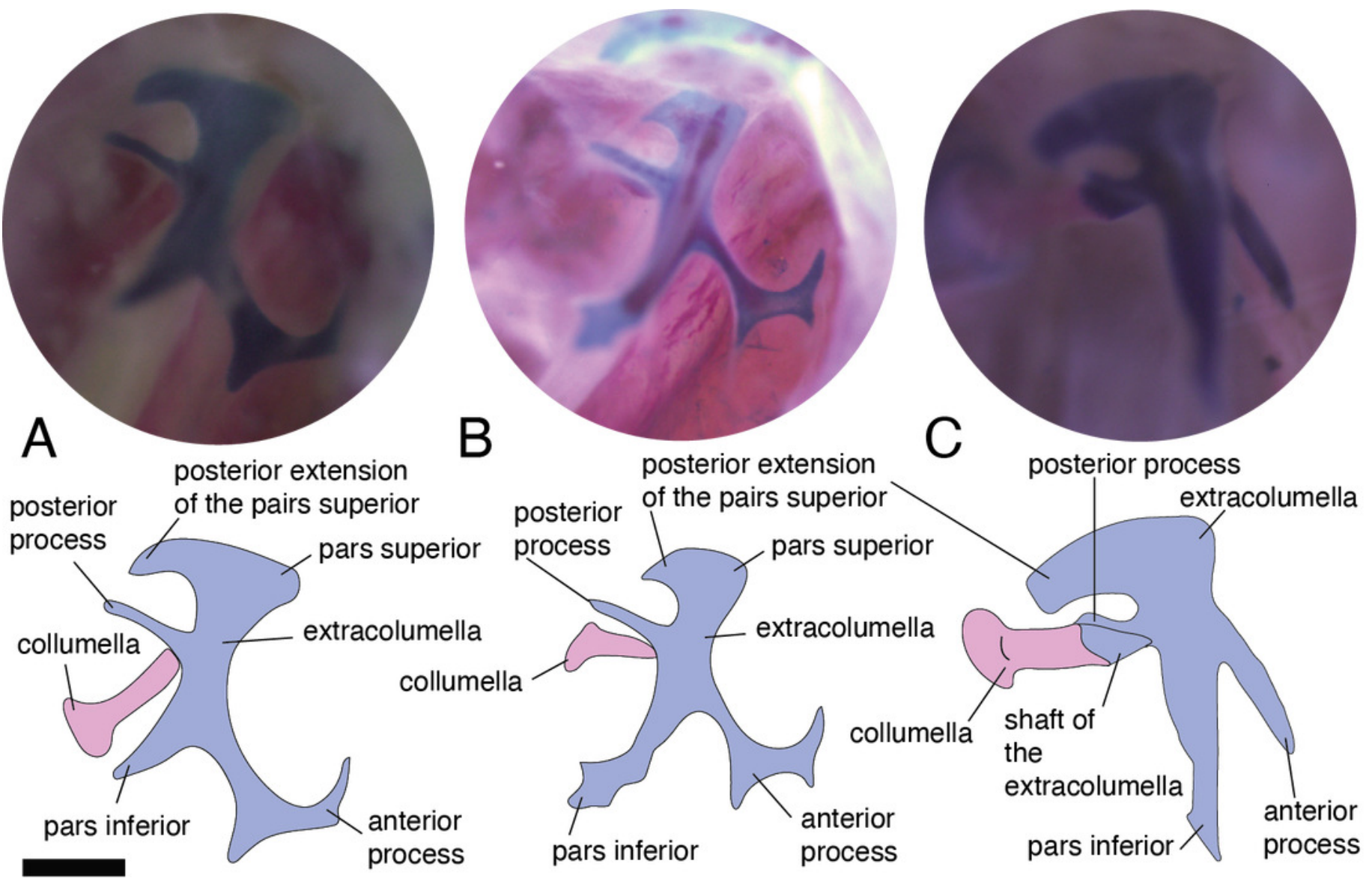




\section{Figure 5}

Extracolumella. The extracolumella is shown from different views of the skull. The columella and the extracolumella (with its corresponding extracolumellar processes), have been sketched.

(A) Gonatodes concinnatus MUJ 733 (from the lateral view of the skull); (B) Morunasaurus groi ICN 6270 (from the posterior view of the skull); (C) Tropidurus pinima MZUSP 92140 (from the ventrolateral view of the skull). Scale bars: $1 \mathrm{~mm}$.
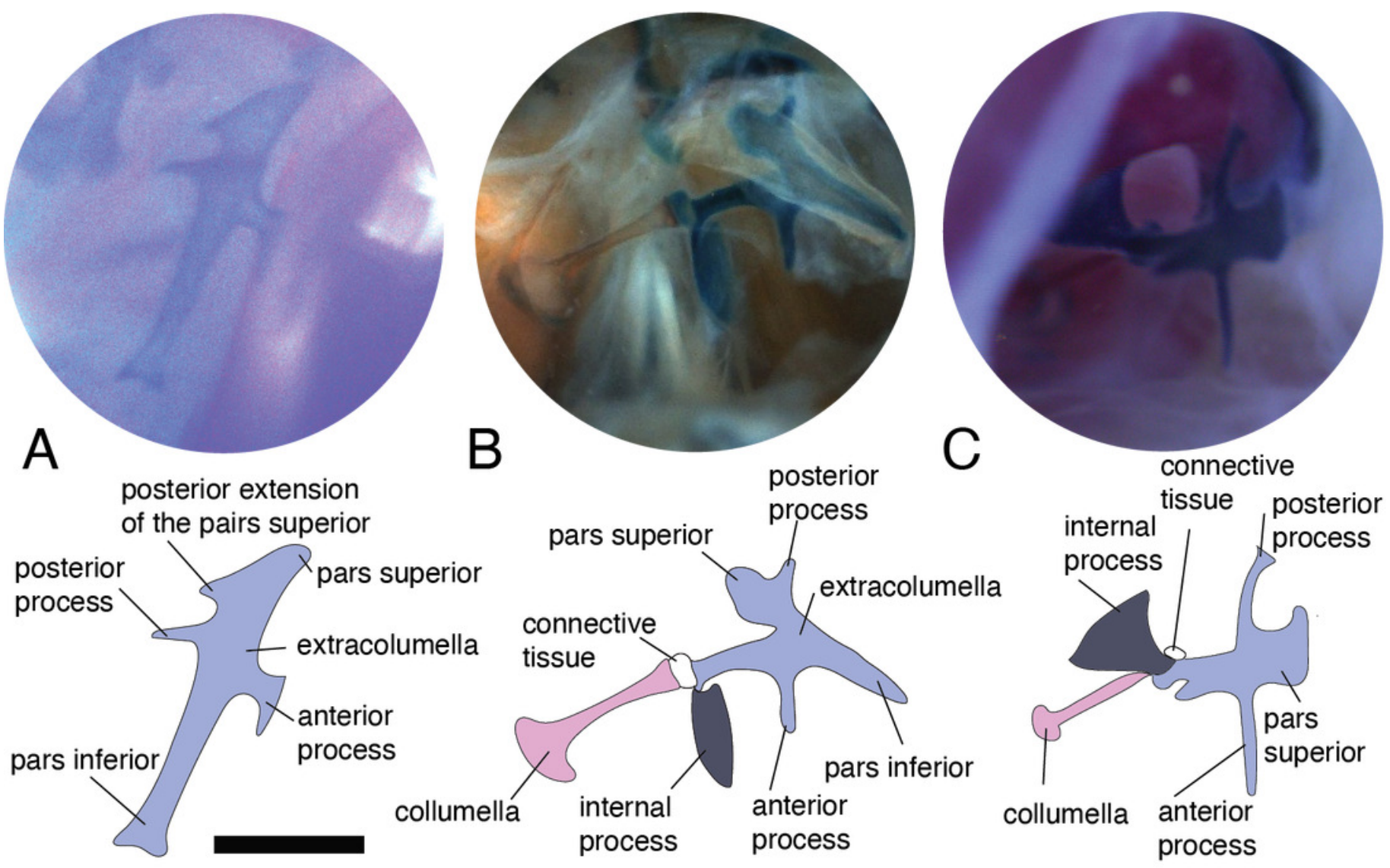


\section{Figure 6}

Extracolumella. The extracolumella is shown from different views of the skull. The columella and the extracolumella (with its corresponding extracolumellar processes), have been sketched.

(A) Gelanosaurus cochrane ICN 9453 (from the lateral view of the skull); (B) Stellagama stellio MZUSP 95176 (from the lateral view of the skull); (C) Mabuya falconensis ICN 11312 (from the posterior view of the skull). Scale bars: $1 \mathrm{~mm}$.
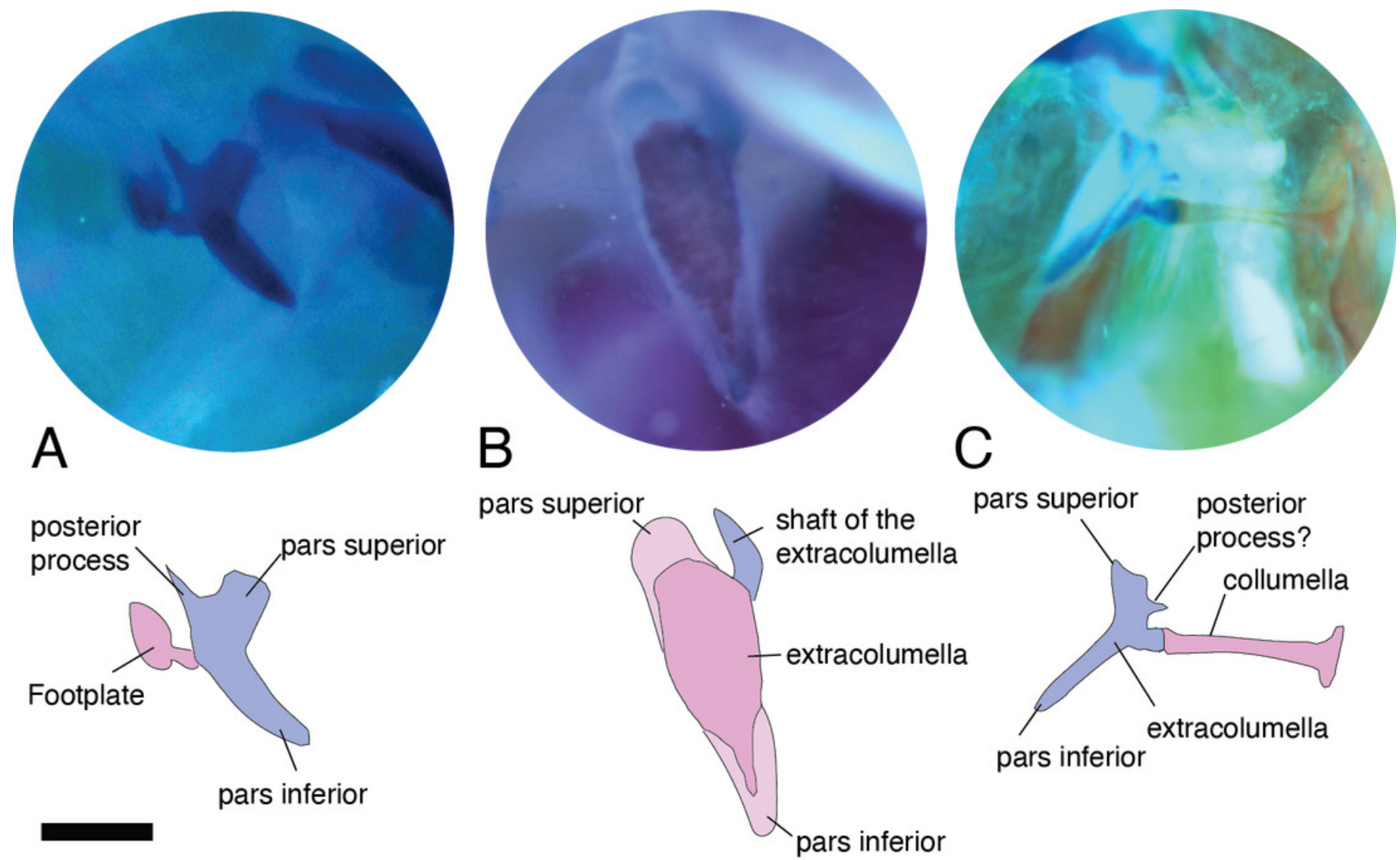

pars inferior 
Figure 7

Summary of the mapping of the characters using maximum parsimony (MP).

Character 1. Length of the columella relative to the extracolumella central axis length.

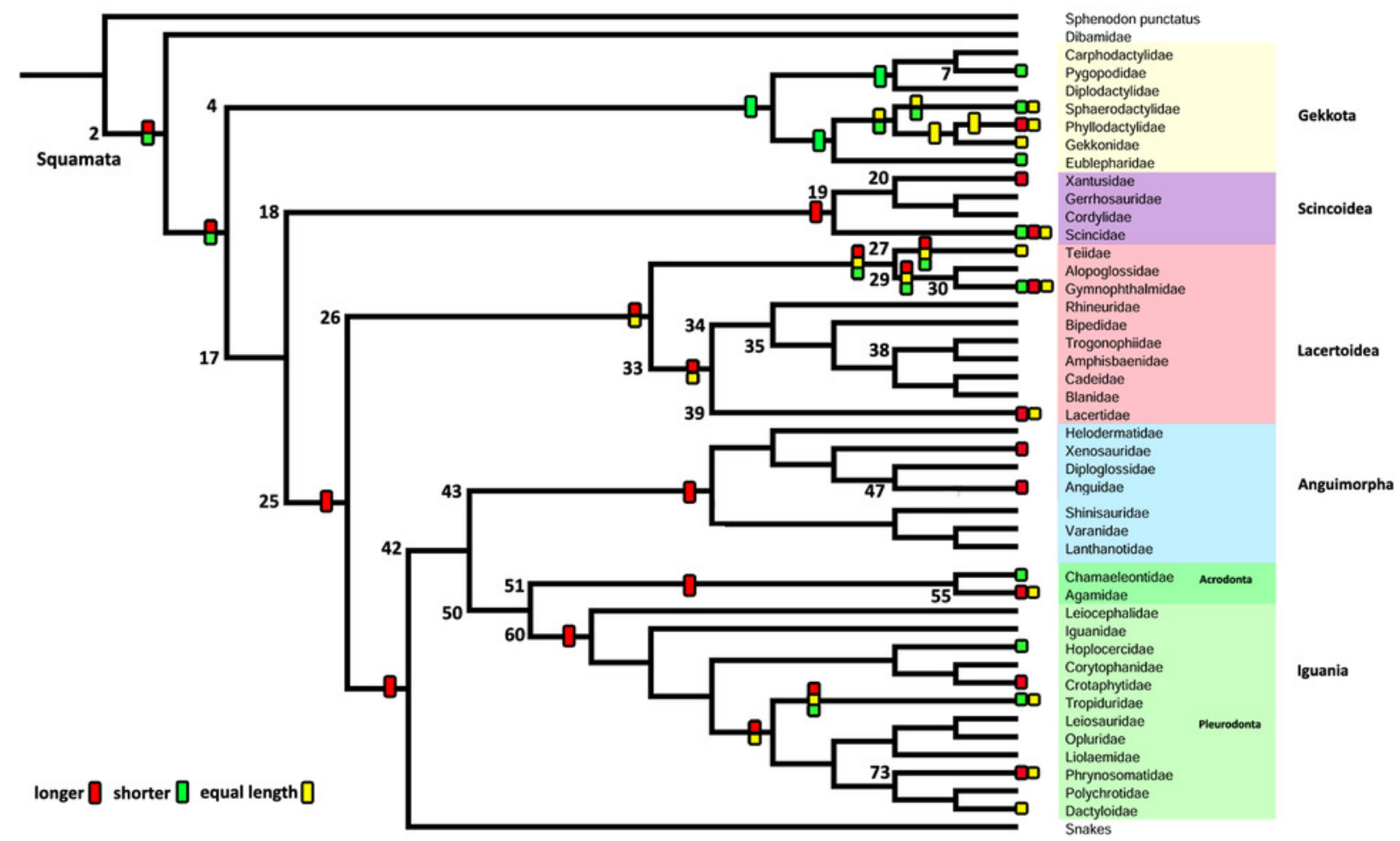


Figure 8

Summary of the mapping of the characters using maximum parsimony (MP).

(A) Character 2. Extracolumella. (B) Character 3. Internal Process. 


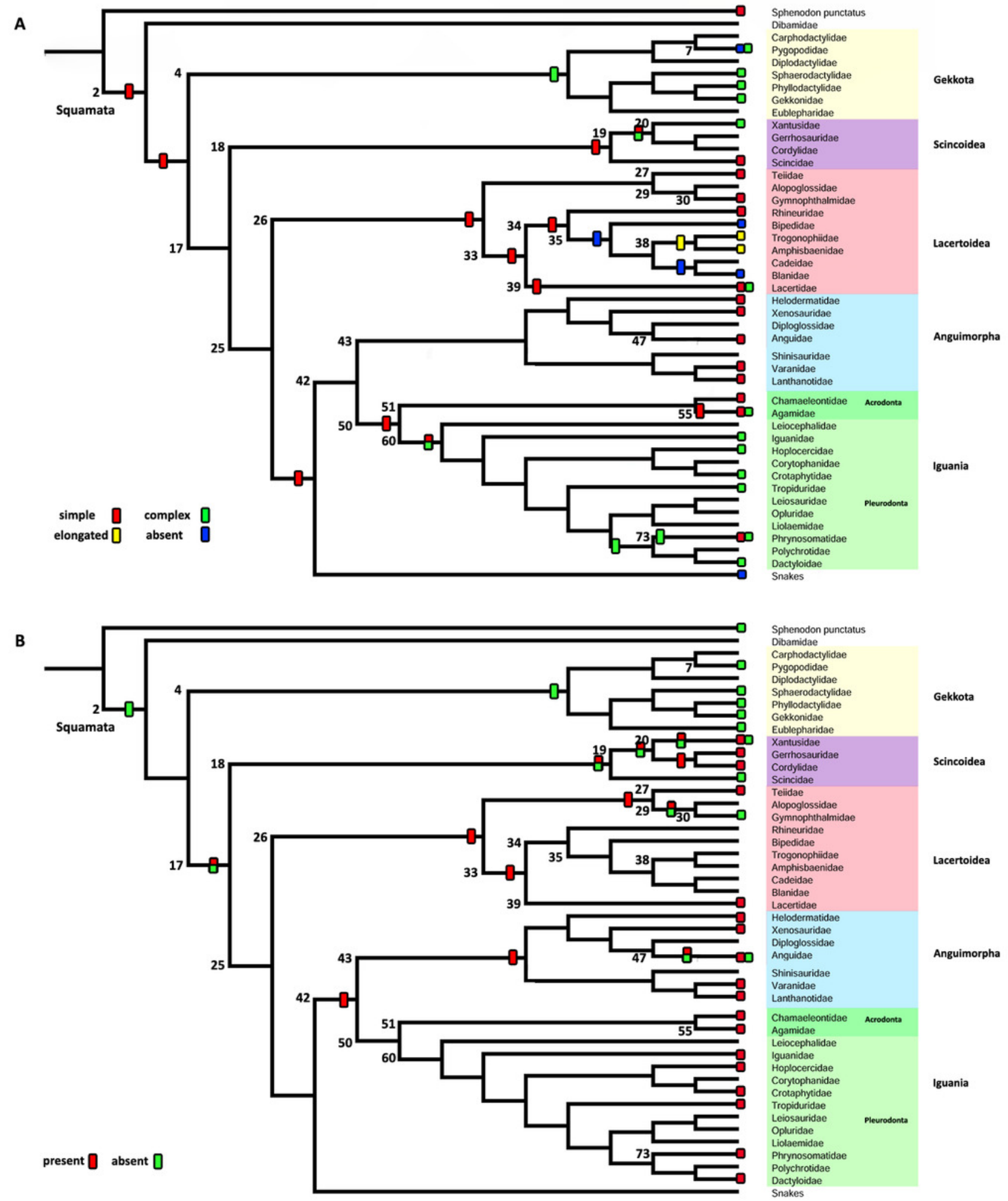




\section{Table 1 (on next page)}

Species and number of specimens examined. 
1 Species and number of specimens examined.

2

3

\begin{tabular}{|c|c|c|c|c|}
\hline Group & Family & Genus & Species & $\begin{array}{l}\text { Number of } \\
\text { Specimens }\end{array}$ \\
\hline \multirow[t]{7}{*}{ Gekkota } & \multirow[t]{2}{*}{ Gekkonidae } & Hemidactylus & H. brasilianus & 1 \\
\hline & & Phelsuma & P. madagascariensis & 1 \\
\hline & \multirow[t]{2}{*}{ Phyllodactylidae } & Tarentola & T. mauritanica & 1 \\
\hline & & Thecadactylus & T. rapicauda & 1 \\
\hline & Pygopodidae & Lialis & L. jicari & 1 \\
\hline & \multirow[t]{2}{*}{ Sphaerodactylidae } & \multirow[t]{2}{*}{ Gonatodes } & G. albogularis & 1 \\
\hline & & & G. concinnatus & 1 \\
\hline \multirow[t]{17}{*}{ Iguania } & \multirow[t]{3}{*}{ Agamidae } & Acanthocercus & A. atricollis & 1 \\
\hline & & Leiolepis & L. belliana & 1 \\
\hline & & Stellagama & S. stellio & 1 \\
\hline & \multirow[t]{9}{*}{ Dactyloidae } & \multirow[t]{9}{*}{ Anolis } & A. antonii & 2 \\
\hline & & & A. auratus & 2 \\
\hline & & & A. chrysolepis & 2 \\
\hline & & & A. fuscoauratus & 1 \\
\hline & & & A. maculiventris & 4 \\
\hline & & & A. mariarum & 3 \\
\hline & & & A. tolimensis & 2 \\
\hline & & & A. trachyderma & 2 \\
\hline & & & A. ventrimaculatus & 3 \\
\hline & \multirow[t]{2}{*}{ Hoplocercidae } & Hoplocercus & H. spinosus & 1 \\
\hline & & Morunasaurus & M. groi & 1 \\
\hline & \multirow[t]{3}{*}{ Tropiduridae } & Stenocercus & S. erythrogaster & 1 \\
\hline & & Tropidurus & S. trachycephalus & 2 \\
\hline & & & T. pinima & 1 \\
\hline \multirow[t]{10}{*}{ Lacertoidea } & \multirow[t]{8}{*}{ Gymnophthalmidae } & Anadia & A. bogotensis & 4 \\
\hline & & Gelanesaurus & G. cochranae & 1 \\
\hline & & Loxopholis & L. rugiceps & 1 \\
\hline & & Neusticurus & N. medemi & 1 \\
\hline & & \multirow[t]{2}{*}{ Pholidobolus } & P. montium & 2 \\
\hline & & & P. vertebralis & 1 \\
\hline & & Riama & R. striata & 3 \\
\hline & & Tretioscincus & T. bifasciatus & 1 \\
\hline & Teiidae & Cnemidophorus & C. lemniscatus & 1 \\
\hline & Lacertidae & Acanthodactylus & A. cf. schmidti & 1 \\
\hline \multirow[t]{4}{*}{ Scincoidea } & \multirow[t]{4}{*}{ Scincidae } & \multirow[t]{4}{*}{ Mabuya } & M. falconensis & 1 \\
\hline & & & M. nigropunctatum & 2 \\
\hline & & & Mabuya sp. 1 & 2 \\
\hline & & & Mabuya sp. 2 & 3 \\
\hline
\end{tabular}

4 The taxonomic classification follows Zheng and Wiens (2016). 


\section{Table 2 (on next page)}

Characterization of the morphological variation of the columella, and the joint with the extracolumella. 
1 Characterization of the morphological variation of the columella, and the joint with the

2 extracolumella.

3

\begin{tabular}{|c|c|c|c|c|}
\hline \multirow[b]{2}{*}{ Species } & \multicolumn{3}{|c|}{ Columella } & \multirow{2}{*}{$\begin{array}{c}\text { Joint of stapes } \\
\text { Connective tissue }\end{array}$} \\
\hline & $\begin{array}{l}\text { Stapedial } \\
\text { foramen }\end{array}$ & $\begin{array}{l}* \text { Length } \\
\text { of the } \\
\text { columella }\end{array}$ & $\begin{array}{l}\text { Widening } \\
\text { of the } \\
\text { osseous } \\
\text { distal end }\end{array}$ & \\
\hline \multicolumn{5}{|l|}{ GEKKOTA } \\
\hline \multicolumn{5}{|l|}{ Gekkonidae } \\
\hline Hemidactylus brasilianus & present & equal & absent & absent \\
\hline Phelsuma madagascariensis & present & equal & present & absent \\
\hline \multicolumn{5}{|l|}{ Phyllodactylidae } \\
\hline Tarentola mauritanica & present & longer & absent & $\begin{array}{l}\text { surrounding } \\
\text { the joint }\end{array}$ \\
\hline Thecadactylus rapicauda & absent & equal & absent & absent \\
\hline \multicolumn{5}{|l|}{ Pygopodidae } \\
\hline Lialis jicari & absent & shorter & present & absent \\
\hline \multicolumn{5}{|l|}{ Sphaerodactylidae } \\
\hline Gonatodes albogularis & present & shorter & absent & absent \\
\hline Gonatodes concinnatus & present & shorter & absent & absent \\
\hline \multicolumn{5}{|l|}{ IGUANIA } \\
\hline \multicolumn{5}{|l|}{ Agamidae } \\
\hline Acanthocercus atricollis & $?$ & longer & present & $\begin{array}{l}\text { surrounding } \\
\text { the joint }\end{array}$ \\
\hline Leiolepis belliana & $?$ & $?$ & absent & absent \\
\hline Stellagama stellio & $?$ & $?$ & $?$ & $?$ \\
\hline \multicolumn{5}{|l|}{ Dactyloidae } \\
\hline Anolis antonii & absent & equal & present & between the joint \\
\hline Anolis auratus & absent & equal & present & absent \\
\hline Anolis chrysolepis & absent & equal & present & between the joint \\
\hline Anolis fuscoauratus & absent & equal & present & between the joint \\
\hline Anolis maculiventris & absent & equal & present & between the joint \\
\hline Anolis mariarum & absent & equal & present & $\begin{array}{c}\text { absent / } \\
\text { between the joint }\end{array}$ \\
\hline Anolis tolimensis & absent & equal & present & $\begin{array}{c}\text { surrounding } \\
\text { the joint }\end{array}$ \\
\hline Anolis trachyderma & absent & equal & present & between the joint \\
\hline Anolis ventrimaculatus & absent & equal & present & $\begin{array}{c}\text { absent } \\
\text { between the joint }\end{array}$ \\
\hline \multicolumn{5}{|l|}{ Hoplocercidae } \\
\hline Hoplocercus spinosus & absent & shorter & absent & between the joint \\
\hline Morunasaurus groi & absent & shorter & present & absent \\
\hline \multicolumn{5}{|l|}{ Tropiduridae } \\
\hline Stenocercus erythrogaster & absent & $?$ & absent & absent \\
\hline
\end{tabular}




\begin{tabular}{|c|c|c|c|c|}
\hline Stenocercus trachycephalus & absent & equal & present & $\begin{array}{l}\text { surrounding } \\
\text { the joint }\end{array}$ \\
\hline Tropidurus pinima & absent & shorter & present & absent \\
\hline \multicolumn{5}{|l|}{ LACERTOIDEA } \\
\hline \multicolumn{5}{|l|}{ Gymnophthalmidae } \\
\hline Anadia bogotensis & absent & shorter & $\begin{array}{l}\text { absent } \\
\text { present }\end{array}$ & absent \\
\hline Gelanesaurus cochranae & absent & shorter & absent & $?$ \\
\hline Loxopholis rugiceps & absent & shorter & present & absent \\
\hline Neusticurus medemi & absent & shorter & absent & absent \\
\hline Pholidobolus montium & absent & shorter & absent & $?$ \\
\hline Pholidobolus vertebralis & absent & shorter & present & absent \\
\hline Riama striata & absent & equal & absent & $\begin{array}{l}\text { surrounding } \\
\text { the joint }\end{array}$ \\
\hline Tretioscincus bifasciatus & absent & longer & present & $\begin{array}{l}\text { surrounding } \\
\text { the joint }\end{array}$ \\
\hline \multicolumn{5}{|l|}{ Teiidae } \\
\hline Cnemidophorus lemniscatus & absent & $?$ & absent & absent \\
\hline \multicolumn{5}{|l|}{ Lacertidae } \\
\hline Acanthodactylus cf. schmidti & absent & equal & present & $\begin{array}{l}\text { surrounding } \\
\text { the joint }\end{array}$ \\
\hline \multicolumn{5}{|l|}{ SCINCOIDEA } \\
\hline \multicolumn{5}{|l|}{ Scincidae } \\
\hline Mabuya falconensis & absent & equal & present & absent \\
\hline Mabuya nigropunctatum & absent & longer & present & between the joint \\
\hline Mabuya sp. 1 & absent & equal & present & absent \\
\hline Mabuya sp. 2 & absent & equal & present & between the joint \\
\hline
\end{tabular}

$5 \quad(*)$ Length of the columella relative to that of the vertical axis of the extracolumella; (?) the 6 condition of the specimen negated the ability to define this feature. 
Table 3 (on next page)

Characterization of the morphological variation of the extracolumella. 


\begin{tabular}{|c|c|c|c|c|c|}
\hline Species & Pars superior & $\begin{array}{c}\text { Pars } \\
\text { inferior }\end{array}$ & Anterior process & Posterior process & $\begin{array}{l}\text { Internal } \\
\text { process }\end{array}$ \\
\hline \multicolumn{6}{|l|}{ GEKKOTA } \\
\hline \multicolumn{6}{|l|}{ Gekkonidae } \\
\hline Hemidactylus brasilianus & $\begin{array}{l}\text { - posterior extension } \\
\text { downward } \\
\text { - straight upper edge }\end{array}$ & $\begin{array}{l}\text { thick with } \\
\text { projections }\end{array}$ & $\begin{array}{l}\text { long with small } \\
\text { projections }\end{array}$ & short and pointed & absent \\
\hline Phelsuma madagascariensis & $\begin{array}{l}\text { - posterior extension } \\
\text { downward } \\
\text { - straight upper edge }\end{array}$ & sharp & $\begin{array}{l}\text { long with small } \\
\text { projections }\end{array}$ & extended and thin & absent \\
\hline \multicolumn{6}{|l|}{ Phyllodactylidae } \\
\hline Tarentola mauritanica & $\begin{array}{l}\text { - posterior extension } \\
\text { downward } \\
\text { - straight upper edge }\end{array}$ & sharp & $\begin{array}{l}\text { long with small } \\
\text { projections }\end{array}$ & extended and thin & absent \\
\hline Thecadactylus rapicauda & $\begin{array}{l}\text { - posterior extension } \\
\text { downward } \\
\text { - straight upper edge }\end{array}$ & $\begin{array}{l}\text { thick with } \\
\text { projections }\end{array}$ & $\begin{array}{l}\text { long with small } \\
\text { projections }\end{array}$ & extended and thin & absent \\
\hline \multicolumn{6}{|l|}{ Pygopodidae } \\
\hline Lialis jicari & $\begin{array}{l}\text { - posterior extension } \\
\text { straight } \\
\text { - straight upper edge }\end{array}$ & sharp & $\begin{array}{l}\text { long pointed, } \\
\text { downward }\end{array}$ & $\begin{array}{l}\text { long and thick } \\
\text { turned upward }\end{array}$ & absent \\
\hline \multicolumn{6}{|l|}{ Sphaerodactylidae } \\
\hline Gonatodes albogularis & $\begin{array}{l}\text { - posterior extension } \\
\text { downward } \\
\text { - straight upper edge }\end{array}$ & $\begin{array}{l}\text { thick with } \\
\text { projections }\end{array}$ & short, downward & short and pointed & absent \\
\hline Gonatodes concinnatus & $\begin{array}{l}\text { - posterior extension } \\
\text { downward } \\
\text { - straight upper edge }\end{array}$ & $\begin{array}{l}\text { thick with } \\
\text { projections }\end{array}$ & short, downward & short and pointed & absent \\
\hline \multicolumn{6}{|l|}{ IGUANIA } \\
\hline $\begin{array}{l}\text { Agamidae } \\
\text { Acanthocercus atricollis }\end{array}$ & \multicolumn{4}{|c|}{ Agamidae } & present \\
\hline
\end{tabular}




\begin{tabular}{|c|c|c|c|c|c|}
\hline & - straight upper edge & & straight & & \\
\hline Leiolepis belliana & $\begin{array}{c}\text { - no extension } \\
\text { - straight upper edge }\end{array}$ & sharp & $\begin{array}{l}\text { long pointed and } \\
\text { straight }\end{array}$ & short and pointed & present \\
\hline Stellagama stellio & $\begin{array}{l}\text { - no extension } \\
\text { - rounded upper edge }\end{array}$ & sharp & absent & absent & present \\
\hline \multicolumn{6}{|l|}{ Dactyloidae } \\
\hline Anolis antonii & $\begin{array}{c}\text { - no extension } \\
\text { - straight upper edge }\end{array}$ & sharp & short and pointed & short and pointed & present \\
\hline Anolis auratus & $\begin{array}{c}\text { - no extension } \\
\text { - straight upper edge }\end{array}$ & sharp & short and pointed & short and pointed & present \\
\hline Anolis chrysolepis & $\begin{array}{c}\text { - no extension } \\
\text { - straight upper edge }\end{array}$ & sharp & short and pointed & short and pointed & present \\
\hline Anolis fuscoauratus & $\begin{array}{c}\text { - no extension } \\
\text { - straight upper edge }\end{array}$ & sharp & short and pointed & short and pointed & present \\
\hline Anolis maculiventris & $\begin{array}{c}\text { - no extension } \\
\text { - straight upper edge }\end{array}$ & sharp & short and pointed & short and pointed & present \\
\hline Anolis mariarum & $\begin{array}{c}\text { - no extension } \\
\text { - straight upper edge }\end{array}$ & sharp & short and pointed & short and pointed & present \\
\hline Anolis tolimensis & $\begin{array}{l}\text { - no extension } \\
\text { - straight upper edge }\end{array}$ & sharp & short and pointed & short and pointed & present \\
\hline Anolis trachyderma & $\begin{array}{c}\text { - no extension } \\
\text { - straight upper edge }\end{array}$ & sharp & short and pointed & short and pointed & present \\
\hline Anolis ventrimaculatus & $\begin{array}{c}\text { - no extension } \\
\text { - straight upper edge }\end{array}$ & sharp & short and bifurcated & extended and thin & present \\
\hline \multicolumn{6}{|l|}{ Hoplocercidae } \\
\hline Hoplocercus spinosus & $\begin{array}{l}\text { - no extension } \\
\text { - rounded upper edge }\end{array}$ & sharp & $\begin{array}{l}\text { long pointed and } \\
\text { straight }\end{array}$ & extended and thin & present \\
\hline Morunasaurus groi & $\begin{array}{l}\text { - no extension } \\
\text { - rounded upper edge }\end{array}$ & sharp & $\begin{array}{l}\text { long pointed and } \\
\text { straight }\end{array}$ & short and pointed & present \\
\hline \multicolumn{6}{|l|}{ Tropiduridae } \\
\hline Stenocercus erythrogaster & $\begin{array}{l}\text { - no extension } \\
\text { straight upper edge }\end{array}$ & sharp & $\begin{array}{l}\text { long pointed and } \\
\text { straight }\end{array}$ & extended and thin & present \\
\hline Stenocercus trachycephalus & - no extension & sharp & long pointed and & extended and thin & present \\
\hline
\end{tabular}




\begin{tabular}{|c|c|c|c|c|c|}
\hline Tropidurus pinima & $\begin{array}{l}\text { - straight upper edge } \\
\text { - anterior extension } \\
\text { straight } \\
\text { - straight upper edge }\end{array}$ & sharp & $\begin{array}{c}\text { straight } \\
\text { long pointed and } \\
\text { straight }\end{array}$ & extended and thin & present \\
\hline \multicolumn{6}{|l|}{ LACERTOIDEA } \\
\hline \multicolumn{6}{|l|}{ Gymnophthalmidae } \\
\hline Anadia bogotensis & $\begin{array}{c}\text { - no extension } \\
\text { - straight upper edge }\end{array}$ & sharp & absent & short and pointed & absent \\
\hline Gelanesaurus cochranae & $\begin{array}{c}\text { - no extension } \\
\text { - straight upper edge }\end{array}$ & sharp & absent & short and pointed & absent \\
\hline Loxopholis rugiceps & $\begin{array}{c}\text { - no extension } \\
\text { - straight upper edge }\end{array}$ & sharp & absent & absent & absent \\
\hline Neusticurus medemi & $\begin{array}{c}\text { - no extension } \\
\text { - straight upper edge }\end{array}$ & sharp & absent & extended and thin & absent \\
\hline Pholidobolus montium & $\begin{array}{c}\text { - no extension } \\
\text { - straight upper edge }\end{array}$ & sharp & absent & short and pointed & absent \\
\hline Pholidobolus vertebralis & $\begin{array}{c}\text { - no extension } \\
\text { - straight upper edge }\end{array}$ & sharp & absent & absent & absent \\
\hline Riama striata & $\begin{array}{c}\text { - no extension } \\
\text { - straight upper edge }\end{array}$ & sharp & absent & short and pointed & absent \\
\hline Tretioscincus bifasciatus & $\begin{array}{c}\text { - no extension } \\
\text { - straight upper edge }\end{array}$ & sharp & absent & short and pointed & absent \\
\hline \multicolumn{6}{|l|}{ Teiidae } \\
\hline Cnemidophorus lemniscatus & $\begin{array}{c}\text { - no extension } \\
\text { - straight upper edge }\end{array}$ & sharp & absent & absent & present \\
\hline \multicolumn{6}{|l|}{ Lacertidae } \\
\hline Acanthodactylus cf. schmidti & $\begin{array}{c}\text { - no extension } \\
\text { - straight upper edge }\end{array}$ & sharp & $\begin{array}{l}\text { long pointed and } \\
\text { straight }\end{array}$ & short and pointed & present \\
\hline \multicolumn{6}{|l|}{ SCINCOIDEA } \\
\hline Mabuya falconensis & $\begin{array}{c}\text { - no extension } \\
\text { - tridentate upper edge }\end{array}$ & sharp & absent & absent & absent \\
\hline Mabuya nigropunctatum & - no extension & sharp & absent & absent & absent \\
\hline
\end{tabular}


- tridentate upper edge

Mabuya sp. 1

- no extension

sharp

absent

absent

absent

Mabuya sp. 2

- tridentate upper edge

- no extension

sharp

absent

absent

absent

- tridentate upper edge 


\section{Table 4 (on next page)}

Sources of the published data used to score the character states of the middle ear. 
Sources of the published data used to score the character states of the middle ear.

\begin{tabular}{|c|c|c|c|}
\hline Group & Family & Species & Reference \\
\hline \multirow[t]{2}{*}{ Rhincocephalia } & Sphenodontidae & Sphenodon punctatus & $\begin{array}{l}\text { Gray (1913), Baird (1970), } \\
\text { Gans \& Wever (1976), Wever (1978) }\end{array}$ \\
\hline & Dibamidae & Anelytropsis papillosus & $\begin{array}{l}\text { McDowell (1967), Greer (1976), } \\
\text { Wever (1978) }\end{array}$ \\
\hline \multirow[t]{10}{*}{ Anguimorpha } & Anguidae & Anguis fragilis & Versluys (1898), Wever $(1973,1978)$ \\
\hline & & Anniella pulchra & Wever $(1973,1978)$ \\
\hline & & Ophisaurus & Baird (1970) \\
\hline & Helodermatidae & Heloderma suspectum & Versluys (1898) \\
\hline & Lanthanotidae & & Wever (1978) \\
\hline & & Lanthanotus borneensis & McDowell (1967), Baird (1970) \\
\hline & Varanidae & Varanus bengalensis & McDowell (1967) \\
\hline & & Varanus niloticus & Versluys (1898) \\
\hline & & Varanus salvator & Han \& Young (2016) \\
\hline & Xenosauridae & Xenosaurus grandis & Wever $(1973,1978)$ \\
\hline \multirow[t]{8}{*}{ Gekkota } & Eublepharidae & Coleonyx variegatus & Posner \& Chiason (1966) \\
\hline & & Eublepharis macularius & Wever (1978), Werner et al. $(2005,2008)$ \\
\hline & Gekkonidae & $\begin{array}{l}\text { Chondrodactylus bibronii } \\
\quad(=\text { Pachydactylus bibronii) }\end{array}$ & Versluys (1898) \\
\hline & & $\begin{array}{l}\text { Gekko gecko } \\
\quad(=\text { Gecko verticillatus }) \\
\text { Hemidactylus garnotti }\end{array}$ & $\begin{array}{l}\text { Versluys (1898), Iordansky (1968), } \\
\text { Wever (1978), Werner \& Wever (1972) } \\
\text { Kluge \& Eckardt (1969) }\end{array}$ \\
\hline & & Narudasia festiva & Daza, Aurich \& Bauer (2012) \\
\hline & & Uroplatus fimbriatus & Versluys (1898) \\
\hline & Pygopodidae & Aprasia sps & Baird (1970), Wever (1978) \\
\hline & & Lialis burtonis & Wever (1974) \\
\hline
\end{tabular}




\begin{tabular}{|c|c|c|c|}
\hline & Sphaerodactylidae & Teratoscincus scincus & $\begin{array}{l}\text { Underwood (1957), McDowell (1967), } \\
\text { Baird (1970), Greer (1976) }\end{array}$ \\
\hline \multirow[t]{18}{*}{ Iguania } & Agamidae & $\begin{array}{l}\text { Bronchocela jubata } \\
\quad(=\text { Calotes jubatus })\end{array}$ & Versluys (1898) \\
\hline & & Ceratophora stoddarti & Wever $(1973,1978)$ \\
\hline & & Ceratophora tennenti & Wever $(1973,1978)$ \\
\hline & & Draco Volans & Versluys (1898), Wever $(1973,1978)$ \\
\hline & & Phrynocephalus maculatus & Wever $(1973,1978)$ \\
\hline & & Phrynocephalus sp. & Wever (1973) \\
\hline & & Uromastyx aegyptia & Versluys (1898) \\
\hline & Chamaleonidae & Chamaeleo & Versluys (1898), Wever $(1968,1978)$ \\
\hline & & Rhampholeon & Toerien $(1963)$ \\
\hline & Crotaphytidae & Crotaphytus collaris & Wever and Werner (1970), Wever (1978) \\
\hline & Iguanidae & $\begin{array}{l}\text { Iguana iguana } \\
\quad(=\text { Iguana tuberculata })\end{array}$ & Versluys (1898) \\
\hline & Phrynosomatidae & Callisaurus draconoides & Earle (1961c), Wever $(1973,1978)$ \\
\hline & & Cophosaurus texanus & Wever $(1973,1978)$ \\
\hline & & Holbrookia & Earle (1961a; 1961c), Baird (1970) \\
\hline & & Holbrookia maculate & Earle (1961a; 1961c), Wever $(1973,1978)$ \\
\hline & & Phrynosoma coronatum & Wever (1973) \\
\hline & & Phrynosoma platyrhinos & Wever $(1973,1978)$ \\
\hline & & Sceloporus magister & Wever $(1967,1973,1978)$ \\
\hline \multirow[t]{10}{*}{ Lacertoidea } & Amphisbaenidae & Amphisbaena & Gans \& Wever (1972), \\
\hline & & & $\begin{array}{l}\text { Wever \& Gans (1973), Olson (1966), } \\
\text { Wever (1973) }\end{array}$ \\
\hline & & Amphisbaena alba & Wever \& Gans (1973) \\
\hline & & Amphisbaena darwini trachura & Wever \& Gans (1973) \\
\hline & & Amphishenia manni & Wever \& Gans (1973) \\
\hline & & Amphisbaena fuliginosa & Versluys (1898) \\
\hline & & Amphisbaena manni & Wever \& Gans (1973) \\
\hline & & Chirindia langi & Wever \& Gans (1973) \\
\hline & & Cynisca leucura & Wever \& Gans (1973) \\
\hline & & Monopeltis c. capensis & Wever \& Gans (1973) \\
\hline
\end{tabular}




\begin{tabular}{|c|c|c|}
\hline & & Zygaspis violacea \\
\hline & Bipedidae & Bipes biporus \\
\hline & Blanidae & Blanus \\
\hline & Lacertidae & Podarcis muralis \\
\hline & & $\begin{array}{l}\text { (=Lacerta muralis }) \\
\text { Timon lepidus }\end{array}$ \\
\hline & & $(=$ Lacerta ocellata $)$ \\
\hline & Rhineuridae & Rhineura floridana \\
\hline & Teiidae & Aspidoscelis tigris aethiops \\
\hline & & $\begin{array}{l}(=\text { Cnemidophorus tessellatus } \\
\text { aethiops })\end{array}$ \\
\hline & & $\begin{array}{l}\text { aethiops) } \\
\text { Pholidoscelis lineolatus }\end{array}$ \\
\hline & & $(=$ Ameiva lineolata $)$ \\
\hline & & Tupinambis teguixin \\
\hline & & (= Tupinambis nigropunctatus) \\
\hline & Trogonophidae & Diplometopon zarudnyi \\
\hline & & Trogonophis wiegmanni \\
\hline Scincoidea & Cordylidae & \\
\hline & Gerrhosauridae & Gerrhosaurus m. major \\
\hline & Scincidae & Acontias plumbeus \\
\hline & & $\begin{array}{l}\text { Eutropis multifasciata } \\
\qquad(=\text { Mabuia multifasciata) }\end{array}$ \\
\hline & & $\begin{array}{l}\text { (= Mabuia multifasciata }) \\
\text { Feylinia currori }\end{array}$ \\
\hline & & Feylinia polylepis \\
\hline & & Scelotes bipes \\
\hline & & Trachylepis brevicollis \\
\hline & & $(=$ Mabuya brevicollis $)$ \\
\hline & Xantusiidae & Lepidophyma gaigeae \\
\hline & & Lepidophyma flavimaculatum, \\
\hline & & Lepidophyma smithi \\
\hline & & Xantusia henshawi \\
\hline & & Xantusia riversiana \\
\hline & & $(=$ Klauberrina riversiana $)$ \\
\hline
\end{tabular}

Wever \& Gans (1973)

Wever \& Gans (1972), Wever (1978)

Gans \& Wever (1975), Wever (1978)

Wever (1978)

Versluys (1898)

Baird (1970), Olson (1966)

Peterson (1966)

Wever (1978)

Versluys (1898)

Gans \& Wever (1975)

Wever \& Gans (1973)

Wever (1978)

Wever (1978)

Wever (1978)

Versluys (1898)

Greer (1976)

Greer (1976)

Torien (1963)

Wever $(1973,1978)$

Greer (1976), Wever (1978)

Wever (1978)

Wever (1978)

Greer (1976), Wever (1978)

Greer (1976) 


\section{Table 5 (on next page)}

Summary of the posterior probabilities estimated for each node by the Bayesian Ancestral State Reconstructions modelled using the models with all rates different $(A R D)$ and equal rates (ER). 
1 Summary of the posterior probabilities estimated for each node by the Bayesian Ancestral

2 State Reconstructions modelled using the models with all rates different (ARD) and equal

3 rates (ER).

4

\begin{tabular}{ccccccccc}
\hline & \multicolumn{3}{c}{ Character 1 ARD model } & \multicolumn{5}{c}{ Character 1 ER model } \\
\hline Node & - & Equal & Longer & shorter & - & equal & longer & shorter \\
\hline 2 & 0,13 & 0,31 & $\mathbf{0 , 3 3}$ & 0,23 & 0,25 & 0,25 & 0,25 & 0,25 \\
4 & 0,13 & 0,31 & $\mathbf{0 , 3 3}$ & 0,23 & 0,25 & 0,25 & 0,25 & 0,25 \\
7 & 0,13 & 0,31 & $\mathbf{0 , 3 3}$ & 0,23 & 0,25 & 0,25 & 0,25 & 0,25 \\
17 & 0,14 & 0,31 & $\mathbf{0 , 3 2}$ & 0,23 & 0,25 & 0,25 & 0,25 & 0,25 \\
18 & 0,13 & 0,31 & $\mathbf{0 , 3 3}$ & 0,23 & 0,25 & 0,25 & 0,25 & 0,25 \\
19 & 0,13 & 0,31 & $\mathbf{0 , 3 3}$ & 0,23 & 0,25 & 0,25 & 0,25 & 0,25 \\
20 & 0,13 & 0,31 & $\mathbf{0 , 3 3}$ & 0,23 & 0,25 & 0,25 & 0,25 & 0,25 \\
25 & 0,13 & 0,31 & $\mathbf{0 , 3 3}$ & 0,23 & 0,25 & 0,25 & 0,25 & 0,25 \\
26 & 0,13 & 0,31 & $\mathbf{0 , 3 3}$ & 0,23 & 0,25 & 0,25 & 0,25 & 0,25 \\
27 & 0,13 & 0,31 & $\mathbf{0 , 3 3}$ & 0,23 & 0,25 & 0,25 & 0,25 & 0,25 \\
29 & 0,14 & 0,31 & $\mathbf{0 , 3 2}$ & 0,23 & 0,25 & 0,25 & 0,25 & 0,25 \\
30 & 0,13 & 0,31 & $\mathbf{0 , 3 3}$ & 0,23 & 0,25 & 0,25 & 0,25 & 0,25 \\
33 & 0,13 & 0,31 & $\mathbf{0 , 3 3}$ & 0,23 & 0,25 & 0,25 & 0,25 & 0,25 \\
34 & 0,13 & 0,31 & $\mathbf{0 , 3 3}$ & 0,23 & 0,25 & 0,25 & 0,25 & 0,25 \\
35 & 0,13 & 0,31 & $\mathbf{0 , 3 3}$ & 0,23 & 0,25 & 0,25 & 0,25 & 0,25 \\
38 & 0,13 & 0,31 & $\mathbf{0 , 3 3}$ & 0,23 & 0,25 & 0,25 & 0,25 & 0,25 \\
39 & 0,13 & 0,31 & $\mathbf{0 , 3 3}$ & 0,23 & 0,25 & 0,25 & 0,25 & 0,25 \\
42 & 0,15 & 0,30 & $\mathbf{0 , 3 1}$ & 0,24 & 0,25 & 0,25 & 0,25 & 0,25 \\
43 & 0,13 & 0,31 & $\mathbf{0 , 3 3}$ & 0,23 & 0,25 & 0,25 & 0,25 & 0,25 \\
47 & 0,13 & 0,31 & $\mathbf{0 , 3 3}$ & 0,23 & 0,25 & 0,25 & 0,25 & 0,25 \\
50 & 0,13 & 0,31 & $\mathbf{0 , 3 3}$ & 0,23 & 0,25 & 0,25 & 0,25 & 0,25 \\
51 & 0,13 & 0,31 & $\mathbf{0 , 3 3}$ & 0,23 & 0,25 & 0,25 & 0,25 & 0,25 \\
55 & 0,13 & 0,31 & $\mathbf{0 , 3 3}$ & 0,23 & 0,25 & 0,25 & 0,25 & 0,25 \\
60 & 0,13 & 0,31 & $\mathbf{0 , 3 3}$ & 0,23 & 0,25 & 0,25 & 0,25 & 0,25 \\
73 & 0,13 & 0,31 & $\mathbf{0 , 3 3}$ & 0,23 & 0,25 & 0,25 & 0,25 & 0,25 \\
\hline
\end{tabular}

5

6 Rounded values of the posterior probabilities; the higher values in bold; (-) inapplicable

7 characters. See correspondence between the node and the clades in the Results section.
8

9

10

11

12

13

14 
15

16

\begin{tabular}{ccccccccc}
\hline \multicolumn{10}{c}{ Character 2 ARD model } & \multicolumn{5}{c}{ Character 2 ER model } \\
\hline node & absent & Expanded & extensive & reduced & absent & Expanded & extensive & reduced \\
\hline 2 & 0,01 & 0,04 & 0,00 & $\mathbf{0 , 9 5}$ & 0,00 & 0,07 & 0,00 & $\mathbf{0 , 9 3}$ \\
4 & 0,15 & $\mathbf{0 , 8 2}$ & 0,01 & 0,02 & 0,00 & $\mathbf{0 , 9 9}$ & 0,00 & 0,01 \\
7 & 0,14 & $\mathbf{0 , 8 5}$ & 0,01 & 0,00 & 0,09 & $\mathbf{0 , 9 1}$ & 0,00 & 0,00 \\
17 & 0,00 & 0,01 & 0,00 & $\mathbf{0 , 9 9}$ & 0,00 & 0,04 & 0,00 & $\mathbf{0 , 9 6}$ \\
18 & 0,01 & 0,03 & 0,00 & $\mathbf{0 , 9 6}$ & 0,00 & 0,06 & 0,00 & $\mathbf{0 , 9 4}$ \\
19 & 0,03 & 0,12 & 0,01 & $\mathbf{0 , 8 4}$ & 0,01 & 0,16 & 0,01 & $\mathbf{0 , 8 2}$ \\
20 & 0,14 & $\mathbf{0 , 8 0}$ & 0,02 & 0,04 & 0,00 & $\mathbf{0 , 9 8}$ & 0,00 & 0,02 \\
25 & 0,00 & 0,00 & 0,00 & $\mathbf{1 , 0 0}$ & 0,00 & 0,00 & 0,00 & $\mathbf{1 , 0 0}$ \\
26 & 0,00 & 0,00 & 0,00 & $\mathbf{1 , 0 0}$ & 0,00 & 0,00 & 0,00 & $\mathbf{1 , 0 0}$ \\
27 & 0,00 & 0,00 & 0,00 & $\mathbf{1 , 0 0}$ & 0,00 & 0,00 & 0,00 & $\mathbf{1 , 0 0}$ \\
29 & 0,00 & 0,00 & 0,00 & $\mathbf{1 , 0 0}$ & 0,00 & 0,00 & 0,00 & $\mathbf{1 , 0 0}$ \\
30 & 0,00 & 0,00 & 0,00 & $\mathbf{1 , 0 0}$ & 0,00 & 0,00 & 0,00 & $\mathbf{1 , 0 0}$ \\
33 & 0,00 & 0,00 & 0,00 & $\mathbf{1 , 0 0}$ & 0,00 & 0,00 & 0,00 & $\mathbf{1 , 0 0}$ \\
34 & 0,00 & 0,00 & 0,01 & $\mathbf{0 , 9 9}$ & 0,02 & 0,00 & 0,01 & $\mathbf{0 , 9 7}$ \\
35 & 0,00 & 0,00 & $\mathbf{0 , 9 4}$ & 0,06 & $\mathbf{0 , 5 8}$ & 0,00 & 0,33 & 0,09 \\
38 & 0,00 & 0,00 & $\mathbf{0 , 9 6}$ & 0,04 & 0,30 & 0,00 & $\mathbf{0 , 7 0}$ & 0,00 \\
39 & 0,01 & 0,07 & 0,00 & $\mathbf{0 , 9 2}$ & 0,00 & 0,08 & 0,00 & $\mathbf{0 , 9 2}$ \\
42 & 0,00 & 0,00 & 0,00 & $\mathbf{1 , 0 0}$ & 0,00 & 0,00 & 0,00 & $\mathbf{1 , 0 0}$ \\
43 & 0,00 & 0,00 & 0,00 & $\mathbf{1 , 0 0}$ & 0,00 & 0,00 & 0,00 & $\mathbf{1 , 0 0}$ \\
47 & 0,00 & 0,00 & 0,00 & $\mathbf{1 , 0 0}$ & 0,00 & 0,00 & 0,00 & $\mathbf{1 , 0 0}$ \\
50 & 0,00 & 0,00 & 0,00 & $\mathbf{1 , 0 0}$ & 0,00 & 0,00 & 0,00 & $\mathbf{1 , 0 0}$ \\
51 & 0,00 & 0,00 & 0,00 & $\mathbf{1 , 0 0}$ & 0,00 & 0,00 & 0,00 & $\mathbf{1 , 0 0}$ \\
55 & 0,00 & 0,00 & 0,00 & $\mathbf{1 , 0 0}$ & 0,00 & 0,00 & 0,00 & $\mathbf{1 , 0 0}$ \\
60 & 0,15 & $\mathbf{0 , 8 0}$ & 0,00 & 0,05 & 0,00 & $\mathbf{0 , 9 5}$ & 0,00 & 0,05 \\
73 & 0,18 & $\mathbf{0 , 6 1}$ & 0,00 & 0,21 & 0,00 & $\mathbf{0 , 9 1}$ & 0,00 & 0,09 \\
\hline & & & & & & & & \\
& & 0.00 &
\end{tabular}

Continuation Table 5

6
17

18

19

20

21

22

23

24

25

26

27

28 


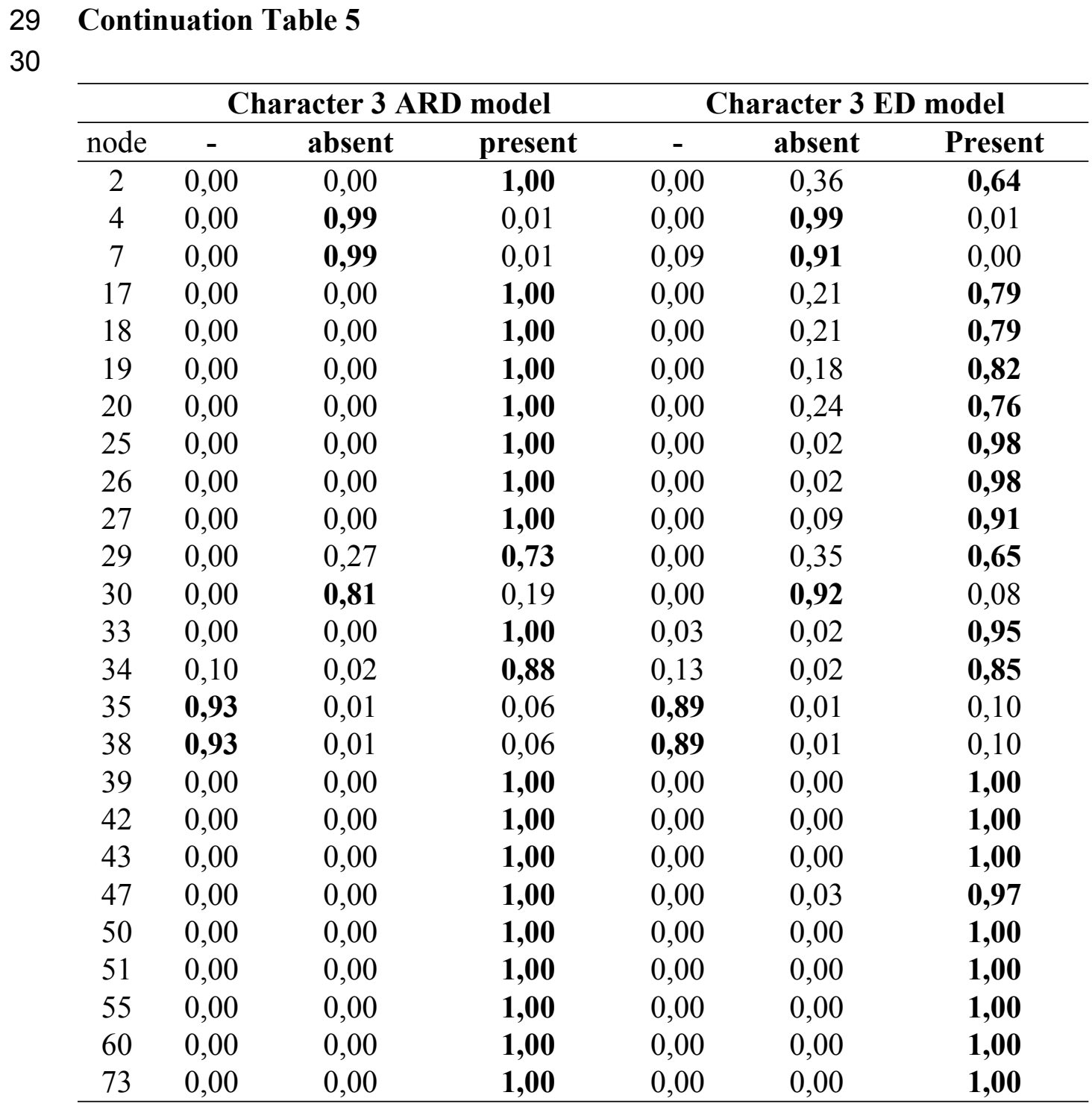

